\title{
Late Quaternary paleoenvironmental records from the Chatanika River valley near Fairbanks (Alaska)
}

\author{
Lutz Schirrmeister ${ }^{\text {a, }}{ }^{*}$, Hanno Meyer ${ }^{\text {a }}$, Andrei Andreev ${ }^{\text {b, c }}$, Sebastian Wetterich ${ }^{\text {a }}$, \\ Frank Kienast ${ }^{\mathrm{d}}$, Anatoly Bobrov ${ }^{\mathrm{e}}$, Margret Fuchs ${ }^{\mathrm{f}}$, Melanie Sierralta ${ }^{\mathrm{g}}$, \\ Ulrike Herzschuh ${ }^{\text {a, }} \mathrm{h}$ \\ a Alfred Wegener Institute Helmholtz Center for Polar and Marine Research, Research Unit Potsdam, Potsdam, Germany \\ ${ }^{\mathrm{b}}$ Institute of Geology and Mineralogy, University of Cologne, Cologne, Germany \\ c Institute of Geology and Petroleum Technologies, Kazan Federal University, Kazan, Russia \\ d Senckenberg Research Institute and Natural History Museum, Research Station for Quaternary Paleontology Weimar, Germany \\ e Department of Soil Science, Moscow State University, Moscow, Russia \\ ${ }^{\mathrm{f}}$ Helmholtz-Zentrum Dresden-Rossendorf, Helmholtz Institute Freiberg for Resource Technology, Freiberg, Germany \\ ${ }^{g}$ Leibniz Institute for Applied Geophysics, Hannover, Germany \\ ${ }^{\mathrm{h}}$ Institute for Earth and Environmental Sciences, University of Potsdam, Potsdam, Germany
}

\section{A R T I C L E I N F O}

\section{Article history:}

Received 21 May 2015

Received in revised form

2 February 2016

Accepted 4 February 2016

Available online $\mathrm{xxx}$

\section{Keywords:}

Permafrost

Interior Alaska

Loess

Cryolithology

Geochronology

Paleoecology

Landscape dynamics

\begin{abstract}
A B S T R A C T
Perennially-frozen deposits are considered as excellent paleoenvironmental archives similar to lacustrine, deep marine, and glacier records because of the long-term and good preservation of fossil records under stable permafrost conditions. A permafrost tunnel in the Vault Creek Valley (Chatanika River Valley, near Fairbanks) exposes a sequence of frozen deposits and ground ice that provides a comprehensive set of proxies to reconstruct the late Quaternary environmental history of Interior Alaska. The multi-proxy approach includes different dating techniques (radiocarbon-accelerator mass spectrometry [AMS ${ }^{14} \mathrm{C}$ ], optically stimulated luminescence [OSL], thorium/uranium radioisotope disequilibria $\left[{ }^{230} \mathrm{Th} / \mathrm{U}\right]$ ), as well as methods of sedimentology, paleoecology, hydrochemistry, and stable isotope geochemistry of ground ice.

The studied sequence consists of 36-m-thick late Quaternary deposits above schistose bedrock. Main portions of the sequence accumulated during the early and middle Wisconsin periods. The lowermost unit A consists of about 9-m-thick ice-bonded fluvial gravels with sand and peat lenses. A late Sangamon (MIS 5a) age of unit A is assumed. Spruce forest with birch, larch, and some shrubby alder dominated the vegetation. High presence of Sphagnum spores and Cyperaceae pollen points to mires in the Vault Creek Valley. The overlying unit B consists of 10-m-thick alternating fluvial gravels, loess-like silt, and sand layers, penetrated by small ice wedges. OSL dates support a stadial early Wisconsin (MIS 4) age of unit B. Pollen and plant macrofossil data point to spruce forests with some birch interspersed with wetlands around the site. The following unit $\mathrm{C}$ is composed of 15 -m-thick ice-rich loess-like and organic-rich silt with fossil bones and large ice wedges. Unit C formed during the interstadial mid-Wisconsin (MIS 3 ) and stadial late Wisconsin (MIS 2) as indicated by radiocarbon ages. Post-depositional slope processes significantly deformed both, ground ice and sediments of unit C. Pollen data show that spruce forests and wetlands dominated the area. The macrofossil remains of Picea, Larix, and Alnus incana ssp. tenuifolia also prove the existence of boreal coniferous forests during the mid-Wisconsin interstadial, which were replaced by treeless tundra-steppe vegetation during the late Wisconsin stadial. Unit C is discordantly overlain by the 2-m-thick late Holocene deposits of unit $\mathrm{D}$. The pollen record of unit $\mathrm{D}$ indicates boreal forest vegetation similar to the modern one.

The permafrost record from the Vault Creek tunnel reflects more than 90 ka of periglacial landscape dynamics triggered by fluvial and eolian accumulation, and formation of ice-wedge polygons and postdepositional deformation by slope processes. The record represents a typical Wisconsin valley-bottom facies in Central Alaska.
\end{abstract}

๑) 2016 Elsevier Ltd. All rights reserved.

\footnotetext{
* Corresponding author.

E-mail address: Lutz.Schirrmeister@awi.de (L. Schirrmeister).
} 


\section{Introduction}

The Quaternary history of the terrestrial Arctic is largely determined by the growing and waning of the ice shields in Eurasia (e.g. Hubberten et al., 2004; Svendsen et al., 2004) and North America (e.g. Gillespie et al., 2004; Ehlers and Gibbard, 2007). Therefore, terrestrial stratigraphical classifications are mostly focused on glacial dynamics and the corresponding landscape dynamics. A prominent exception from glacially-sculptured northern landscapes is Beringia, the predominantly non-glaciated region in Siberia, Alaska, and Northwest Canada between the Laurentide and Scandinavian ice shields (Brigham-Grette, 2001). Intense research of Beringian paleoenvironments was undertaken during the 1980s and 1990s (e.g. Hopkins et al., 1982; West, 1996; Elias and BrighamGrette, 2001). The areas of Interior Alaska unglaciated during the late Pleistocene belong to eastern Beringia which is characterized by frequent occurrence of syngenetic ice-rich permafrost, termed Yedoma (Schirrmeister et al., 2011). Although large parts of Alaskan permafrost belong to the Yedoma permafrost type, studies on its nature, distribution, cryogenic structure, and properties are limited (Kanevskiy et al., 2011).

Permafrost is a widely distributed climate-driven phenomenon of arctic and subarctic regions. Due to long-term stable permafrost conditions frozen deposits are considered to be paleoenvironmental archives comparable to sediment core sequences of lacustrine and deep marine deposits, and to glacier ice cores. Permafrost composed of perennially frozen deposits and ground ice preserves various records of the late Quaternary environment and climate dynamics. While thermokarst, thermoerosion, and slumping processes destroy natural permafrost exposures and limit the possibility of continuous detailed studies and resampling of outcrops, underground excavations and permafrost tunnels serve as three-dimensional natural laboratories for such studies (e.g. Shur et al., 2004).

The presented study shows that aggrading syngenetic permafrost preserves indicators of landscape evolution, especially during cold intervals, in frozen sediment sequences. Fossil proxy data document climate and environmental variations. Sediment features reflect changes in accumulation and transport processes and periglacial landscape dynamics. Ground-ice structures in permafrost deposits are products of freezing, as well as of thawing and refreezing processes during permafrost development. The geochemical and stable-isotope composition of ground ice reflects supra-regional precipitation signals as well as local interrelationships between ground ice and sediments (e.g. Meyer et al., 2015). The geochronological determination of the studied sediments provides an essential base for stratigraphic classifications.

The present study aims to reconstruct the late Quaternary environmental history of Interior Alaska, a key region in eastern Beringia. The permafrost archive of the recently excavated Vault Creek (VC) permafrost tunnel provides data (1) to classify the stratigraphy and geochronology of the sequence, (2) to characterize the properties and formation processes of the ice-rich permafrost deposits (Yedoma), and (3) to reconstruct paleoenvironmental variations during the late Quaternary.

During the first inspections of the VC tunnel in 2004 several ice wedge generations were recognized and related to repeated alterations of cold and warm periods (Meyer et al., 2008). Our initial hypothesis suspected that the entire sequence could date back to the Illinoian (MIS 8-MIS 6, 300-130 ka) or even beyond (MIS 13MIS $12,500 \mathrm{ka}$ ). In order to test this hypothesis, it was crucial to perform a complete cryolitho-stratigraphical and geochronological classification of the permafrost sequence as well as biostratigraphical studies in the VC tunnel.

\section{Study area}

The region around Fairbanks belongs to the discontinuous permafrost zone (Jorgenson et al., 2008). Permafrost reaches up to $120 \mathrm{~m}$ in thickness and is relatively warm with a mean annual ground temperature of $-0.7 \quad \mathrm{C}$ at the tunnel site (http:// gtnpdatabase.org/boreholes/view/609/). In the study area, permafrost usually occurs below valley bottoms and north-facing slopes, but is largely absent on south-facing slopes. Central Alaska is characterized by a continental climate with mean annual air temperature of about $-3.0{ }^{\circ} \mathrm{C}$ and annual precipitation of about $263 \mathrm{~mm}$ (at the Fairbanks airport, 1971-2000). Presently, sprucebirch-aspen taiga dominates the vegetation in the area (Viereck, 1983).

In the Fairbanks area, there are several key sites for the Quaternary, especially for late Pleistocene paleoenvironmental studies, where loess deposits are considered to be the most important paleo-archives (Begét, 1990, 2001). Several volcanic ash layers found therein were used as late Pleistocene stratigraphic markers in Interior Alaska and the surroundings.

The longest loess record exposed at Gold Hill west of Fairbanks covers about 3 Ma (Westgate et al., 1990) including the BrunhesMatuyama reversal (Evans et al., 2011). The Pleistocene sequence of Gold Hill trench $1 \mathrm{~b}$ was dated by different geochronological methods (fission track, ${ }^{10} \mathrm{Be}$, AMS ${ }^{14} \mathrm{C}$, thermoluminescence [TL] and infrared stimulated luminescence [IRSL]) to cover about $600 \mathrm{ka}$ (Berger, 2003; Muhs et al., 2003). The Halfway House site southwest of Fairbanks is a TL-dated sequence spanning from $149 \pm 11 \mathrm{ka}$ to $10 \mathrm{ka}$, but with some internal inversions (Berger, 2003). Both sequences contain several mid-Wisconsin paleosol horizons radiocarbon-dated from $43.9 \pm 2.5$ to $30.9 \pm 0.5 \mathrm{ka} \mathrm{BP}$ (Gold Hill) and $42.2 \pm 2.0$ to $30.6 \pm 0.5 \mathrm{ka}$ BP (Halfway House) (Muhs et al., 2003). Comparable mid-Wisconsin loess sequences are reported from Birch Hill (38.5 \pm 0.8 to $27.6 \pm 0.2 \mathrm{ka} \mathrm{BP})$ and Chena Hot Springs Road (>55.9 to $30.0 \pm 0.2$ ka BP) (Muhs et al., 2003) near Fairbanks.

The best-studied paleoenvironmental record in the Fairbanks area is from the Cold Regions Research and Engineering Laboratory (CRREL) Permafrost Tunnel Research Facility, commonly known as the Fox Tunnel, which was constructed by the U.S. Army Corps of Engineers in 1963-1969 near the hamlet of Fox, just north of Fairbanks (Sellmann, 1967, 1972). The bedrock of weathered Precambrian schist of the Yukon Crystalline Terrane is overlain by the Fox Gravel Horizon that contains willow wood and other tree stumps dated between $>46$ and 41 ka BP (Hamilton et al., 1988). A loess sequence above the gravel radiocarbon-dated between 40 and $30 \mathrm{ka} \mathrm{BP}$ is subdivided into a lower and an upper silt unit. The loess is predominantly characterized by layered and lenticular cryogenic structures (Shur et al., 2004; Kanevskiy et al., 2008) and contains numerous 2-to-4-m-wide foliated ice wedges. In addition 0.5-to-2$\mathrm{m}$ thick and 6-m-wide saucer-shaped ice bodies exist which were interpreted as frozen thaw ponds by Hamilton et al. (1988) and as thermokarst-cave ice by Shur et al. (2004). Ice wedges and cave ice were also studied by Douglas et al. (2011) and Lachniet et al. (2012) for biogeochemical and radiocarbon analyses, respectively. The permafrost sequence of the Fox Tunnel is finished by Holocene alluvial deposits, radiocarbon-dated between 8.5 and 2.5 ka BP. Plant macrofossils, insects, mollusks, and mammal bones from the Fox Tunnel reflect the existence of boreal forest and tundra habitats during the middle Wisconsin (Hamilton et al., 1988).

According to Anderson and Lozhkin (2001) the known midWisconsin interstadial sites provide only discontinuous records, which in combination reflect clear environmental differences between the framing stadial periods. Paleobotanical data especially suggest relatively warm and moist climate conditions during the 
mid-Wisconsin interstadial; however, conditions then were more severe than during the Holocene. For the Fairbanks area, the MIS 3 review of Anderson and Lozhkin (2001) reported warm intervals at ca. $60-50$ and 32-30 ka BP. During the last decade several new paleoecological and stratigraphical studies in the Yukon catchment area were published by colleagues from the University of Alberta (e.g. Reyes et al., 2010a,b, 2011; Zazula et al., 2006, 2011).

Vault Creek is a tributary of the Chatanika River. The VC tunnel $\left(65^{\circ} 01^{\prime} 46.3^{\prime \prime} \mathrm{N} ; 147^{\circ} 42^{\prime} 22.4^{\prime \prime} \mathrm{W}\right)$ is situated about $20 \mathrm{~km}$ north of Fairbanks (Fig. 1). The tunnel site is located near the Elliott Highway about $10 \mathrm{~km}$ NNW Fox tunnel. The VC tunnel, situated on a northfacing slope, was excavated in 1990 by a local private gold miner. The permafrost tunnel is about $40 \mathrm{~m}$ deep and $220 \mathrm{~m}$ long (Fig. 2) and is, to our knowledge, the deepest and longest permafrost tunnel available for permafrost research in Alaska. The entrance to the VC tunnel is secured by a 30-m-long steel tube, which makes the uppermost part of the section inaccessible. The VC tunnel was also studied as a reference site for thermokarst lake methanogenesis by Heslop et al. (2015).

\section{Methods}

Fieldwork in the VC tunnel was conducted in April 2004 and May 2006. The entire tunnel was surveyed using a laser tachymeter and measuring tape, followed by a detailed cryolithological description according to French and Shur (2010) and sampling of the frozen deposits in several partly-overlapping subprofiles (Fig. 2). Deposits were sampled by axe and hammer. Ice wedges were sampled by an electric drilling machine, an electric chain saw, and a small handheld ice screw. In order to access the uppermost part of the frozen sequence a 3-m-deep and 0.6-m-wide shaft was drilled several meters west of the mine entrance using a hydraulic auger in May 2006 (Fig. 3B). All ice and sediment samples were transported in frozen state for further analysis to the laboratories of the Alfred Wegener Institute, Potsdam. A total of 82 sediment and 183 wedge-ice samples were analyzed.

Frozen sediments were freeze-dried and split into subsamples for sedimentological, geochemical, and paleoecological analysis. Before and after freeze-drying the sediment samples were weighed to measure the gravimetric ice content. Grain-size analyses were carried out using a Retsch sieving device and an LS 200 laser particle analyzer (Fa. Beckman-Coulter). Total carbon (TC), total nitrogen (TN), and total organic carbon (TOC) contents were measured with a carbon-nitrogen-sulfur (CNS) VARIO-EL-III Element Analyzer. Using the TOC and TN values, the TOC/TN ratio $(\mathrm{C} / \mathrm{N})$ was calculated to deduce the degree of organic matter decomposition. The lower the $\mathrm{C} / \mathrm{N}$ ratio the higher the decomposition degree, and vice versa (White, 2006; Carter and Gregorich,
2008). For TOC and stable carbon isotope $\left(\delta^{13} \mathrm{C}\right)$ analyses samples were decalcified for $3 \mathrm{~h}$ at $95{ }^{\circ} \mathrm{C}$ by adding a surplus of $1.3 \mathrm{~N} \mathrm{HCl}$. Total inorganic carbon (TIC) content was calculated by subtracting TOC from TC. The TIC values were additionally used to estimate the carbonate content via the ratios of molecular weight in $\mathrm{CaCO}_{3}$. The $\delta^{13} \mathrm{C}$ of TOC values were measured with a Finnigan DELTA $S$ mass spectrometer and expressed in delta per mil notation $(\delta \%)$ relative to the Vienna Pee Dee Belemnite (VPDB) standard with an uncertainty of $0.15 \%$. The variations in $\delta^{13} \mathrm{C}$ are indicators of changes in the local plant association and the decomposition of organic matter (Hoefs, 1997). Lower $\delta^{13} \mathrm{C}$ values correspond to less-decomposed organic matter, while higher $\delta^{13} \mathrm{C}$ values reflect stronger decomposition (Gundelwein et al., 2007). Mass-specific magnetic susceptibility (MS) indicative of magnetic and magnetizable minerals was measured using BARTINGTON MS2 instruments equipped with the MS2B sensor type. The data are expressed in $10^{-8} \mathrm{~m}^{3} \mathrm{~kg}^{-1}(\mathrm{SI})$.

An end-member (EM) modeling algorithm was used to calculate robust EMs from the total set of grain-size distributions with the MATLAB software (R2012a; 7.14.0.739), using the EM Modeling Algorithm (EMMA) developed by Weltje (1997). Model runs considered different numbers of EMs. The minimum number of potential EMs was determined when the cumulative explained variance reached at least 95\%; the maximum number of EMs was determined by the maximum value of the mean coefficient of determination. The robustness of the EMs was then tested and the final robust $\mathrm{EM}(\mathrm{s})$ and residual member(s) was (were) extracted (Dietze et al., 2012).

The radiocarbon ages were determined by AMS ${ }^{14} \mathrm{C}$ dating of wood fragments, plant detritus, or bone collagen. Preparation and measurements were carried out in the Leibniz Laboratory in Kiel, Germany. The plant material was then extracted with $1 \% \mathrm{HCl}, 1 \%$ $\mathrm{NaOH}$ at $60{ }^{\circ} \mathrm{C}$ and again $1 \% \mathrm{HCl}$ (acid-alkali-acid method). Only extracted residues free of humic acids were used for age interpretation. Details of the AMS facility in Kiel are given in Nadeau et al. (1997, 1998), and Grootes et al. (2004). Most of the samples gave enough carbon (about $1 \mathrm{mg}$ ) and produced a sufficiently high ion beam during the AMS measurement. For samples that did not yield $1 \mathrm{mg}$ of carbon, the amount recommended for a precise measurement, the sample gas was reduced on $1 \mathrm{mg}$ Fe (instead of on the usual $2 \mathrm{mg} \mathrm{Fe}$ ) in order to have a better C/Fe ratio and a larger ion current. The Leibniz Laboratory reduces the background inherent to the spectrometer, which results in low background count rates of the detector, equivalent to an apparent age of $75 \mathrm{ka}$ BP (gated background) (Nadeau et al., 1997). In total, 18 radiocarbon dates from various organic materials were obtained.

Plant fragments from a tephra layer at $2 \mathrm{~m}$ b.s. were additionally dated by the Beta Analytic Radiocarbon Dating Laboratory.

Four OSL samples were taken for dating the sediments of unit A
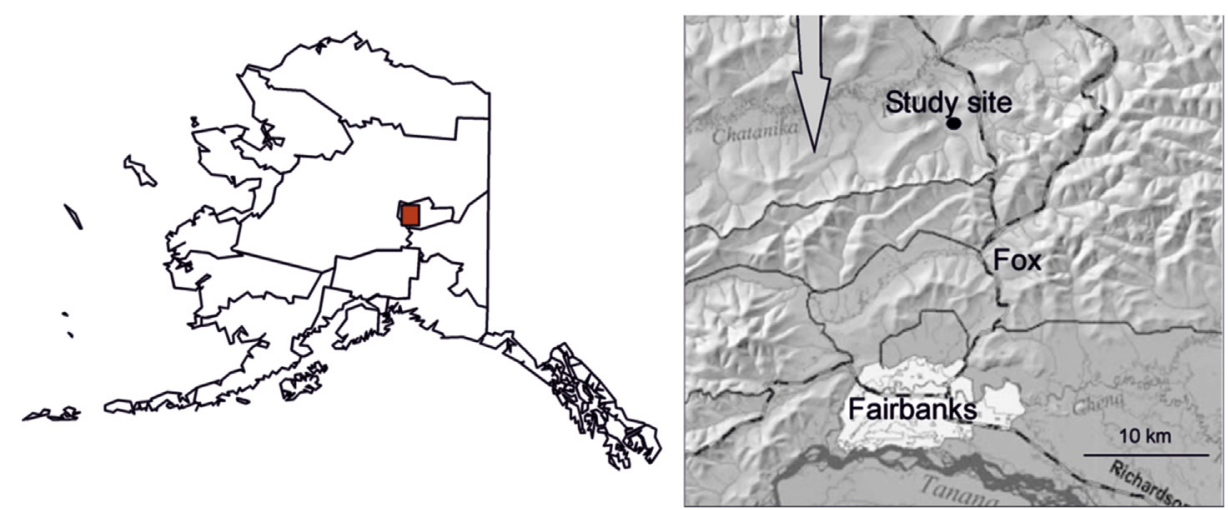

Fig. 1. Location of the study site, the Vault Creek (VC) tunnel north of Fairbanks (Interior Alaska). 


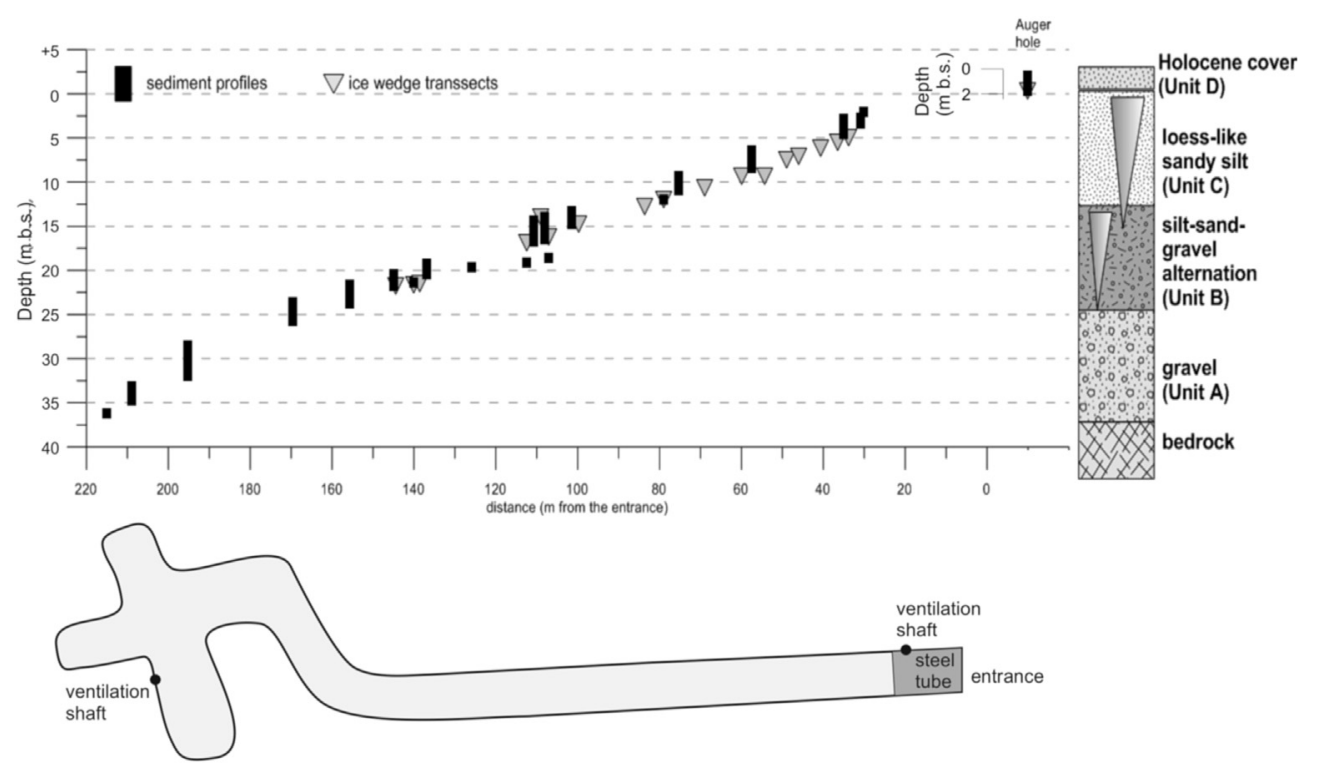

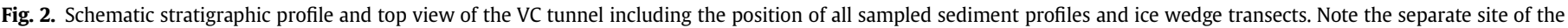
auger hole, several meters several meters west of the tunnel entrance.

and $\mathrm{B}$. The recovery of frozen sediment cores with a hand-drilling machine (HILTI) and a modified drill head for opaque plastic cylinders inside ensured no light exposure during sampling. Sediment surrounding each OSL sample was taken for high-purity Germanium (HP-Ge) $\gamma$-spectrometry. The coarse-grained quartz fraction (90-160 $\mu \mathrm{m})$ was prepared and measured at the Luminescence Laboratory of the Technische Universität (TU) Bergakademie Freiberg (Germany). Sets of 4-mm-diameter aliquots were measured with a Risø DA15 OSL/TL Reader (stimulation: blue LED, $470 \mathrm{~nm}$, detection: Hoya 340 filter, beta source: ${ }^{90} \mathrm{Sr}$, $\left.5.6 \mathrm{Gymin}^{-1}\right)$. Measurements followed the Single-Aliquot Regenerative-dose (SAR) protocol of Murray and Wintle (2000). Preheat and cutheat temperatures were both set to $260{ }^{\circ} \mathrm{C}$. Resulting luminescence signals, equivalent doses and dose distributions were analyzed using the Luminescence R package (Kreutzer et al., 2012). The luminescence signals of the here presented samples show reliable properties with fast decay of intense signals (5-100 thousand counts in the first second) and good dose-response reproducibility (recycling ratios of $\leq 10 \%$ and recuperation $\leq 5 \%$ ).

The statistical modeling of paleodoses requires several considerations, when applied to samples from permafrost environments (e.g. Arnold et al., 2008; Bateman, 2008; Fuchs and Owen, 2008).

Sediment mixing during residence in the active layer may induce a broadening of the equivalent dose scatter until sediment accumulation shifts the sampled unit below the permafrost table. In such environments a relative high dose scatter results from slow sedimentation along with thick active layers. The quality of bleaching during transport may be variable as a variety of processes are possible, but the morphodynamic activity is primarily taking place in the summer season after snowmelt and before the next winter pauses water transport and covers surfaces with snow. Effects of both, grain transport and mixing may be inferred from the skewness and standard deviation of dose distributions. Overdispersion estimates the variation above an expected variability as an indicator of sediment-related effects without bleaching (e.g. Galbraith et al., 1999). Such objective indicators of bleaching and mixing provide the basis of decision procedures for the appropriate age model (e.g. Galbraith et al., 1999; Arnold et al., 2007; Bailey and Arnold, 2006). The sample-specific age-model evaluation accounts for grain histories that may greatly differ between samples, especially in permafrost environments, where variable transport and post-sedimentary grain mixing work together and may alter conditions at small spatial scales. In the case of small data sets or difficult luminescence properties, analyses of dose distributions give only little indication on bleaching or sediment mixing. If so, only the arithmetic mean may deliver an estimate of the burial dose. The limited data sets of FAI-OSL-1 $(\mathrm{N}=5)$ and FAI-OSL-2 $(\mathrm{N}=9)$ primarily relate to the small quartz yield of the 90-160 $\mu \mathrm{m}$ fraction, while luminescence properties are reliable. The only indication on sediment mixing may be inferred from the high variation of grain sizes in this sediment unit (cf. Fig. 4) that coincides with the age inversion of FAI-OSL-2 and FAI-OSL-1 (Table 1).

Further statistical age modeling was possible for the larger data sets of FAI-OSL-3 $(\mathrm{N}=28)$ and FAI-OSL-5 $(\mathrm{N}=35)$ that showed scattered and/or non-normally-distributed dose distributions. Age models designed for such data are the central age model (CAM, Galbraith et al., 1999) and the minimum age model (MAM, Galbraith et al., 1999). FAI-OSL-3 indicated a small degree of differential bleaching or incorporation of older material by a high standard deviation (57.1\%), lower overdispersion (41.2\%) and slight skewness (1.7). Consequently, age calculation was based on the MAM (Table 1). In contrast, the dose distribution of FAI-OSL-5 indicates an incorporation of younger grains by a negative skewness $(-0.55)$. Excluding four low outliers results in a close to normal distribution (skewness of $0.2 \%$ ) and a relatively small standard deviation (18.5\%) compared to a similar overdispersion (15.5\%). Therefore, age calculation for FAI-OSL-5 was based on the CAM (Table 1).

The choice of $4 \mathrm{~mm}$ aliquots implies a certain degree of averaging the signals from individual grains representing the sampled sediment. This inhibits the application of the finite mixture model (FMM, Galbraith and Green, 1990) for dose population unmixing of single grain data (Arnold and Roberts, 2009). However, reported possible problems of dose underestimation in multiple-grain analyses due to signal averaging and incorporation of dim or zero dose grains were found only relevant for small or medium size aliquots, but not for the here used $4 \mathrm{~mm}$ aliquot size (cf. Demuro et al., 2013). In $4 \mathrm{~mm}$ aliquots, the measured signal likely results from several bright grains that mask the effects of problematic grains. All 

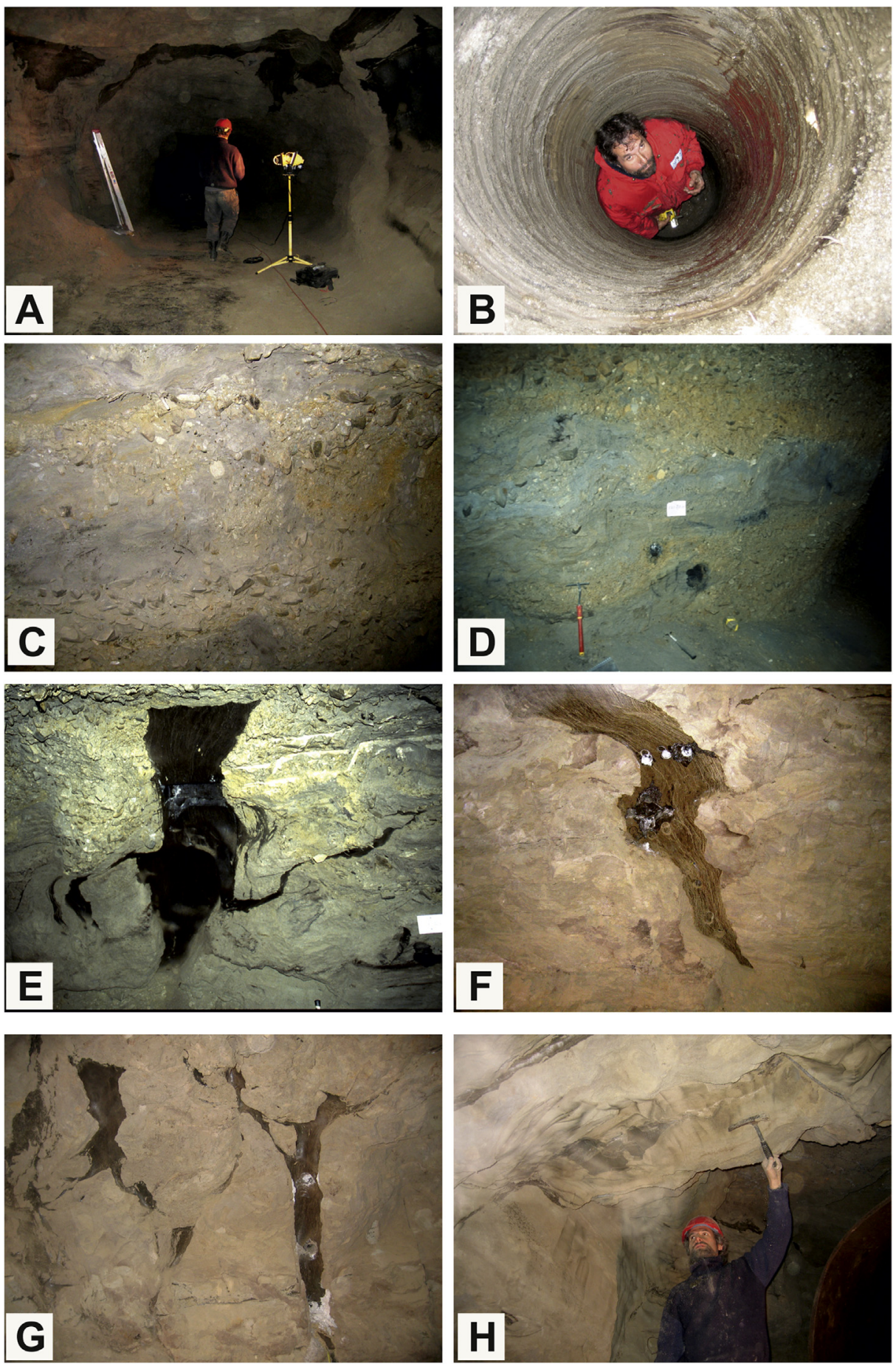

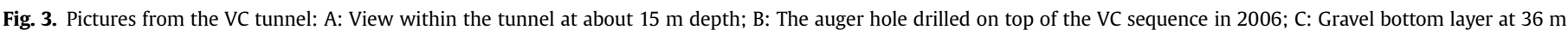

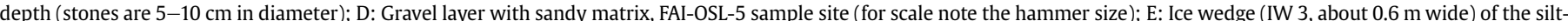

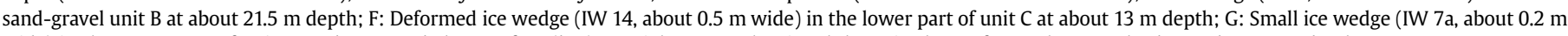
wide) in the upper part of unit $\mathrm{C}$ at about $6 \mathrm{~m}$ below surface (b.s.); H: Light-gray volcanic ash layer in the roof near the tunnel tube at about $2 \mathrm{~m}$ depth.

parameters (paleodose, specific activities of radionuclides, studysite-specific cosmic dose rate, dosimetric corrections) were processed for age calculation using the ADELE software (Kulig, 2005).

Major element analyses of volcanic glass shards (100-125 $\mu \mathrm{m}$ separated under the stereo microscope) from two tephra layers were carried out using the Scanning Electron Microscope Ultra 55 Plus (Carl Zeiss SMT) in combination with the NORANTM System 7 X-ray Microanalysis System (Thermo Scientific) at the GFZ German
Research Centre for Geosciences. Glass shard analyses were performed with an acceleration voltage of $20 \mathrm{kV}$, a large aperture $(120 \mu \mathrm{m})$, and $30 \mathrm{~s}$ of acquisition time. The calculation of the particle chemistry was performed by applying the standardless procedure of the NSS (Noran System Seven).

Peat lenses were specifically sampled for age determination with the ${ }^{230} \mathrm{Th} / \mathrm{U}$ radioisotope disequilibrium method using a thermal ionization mass spectrometer (TIMS, Finnigan MAT262 


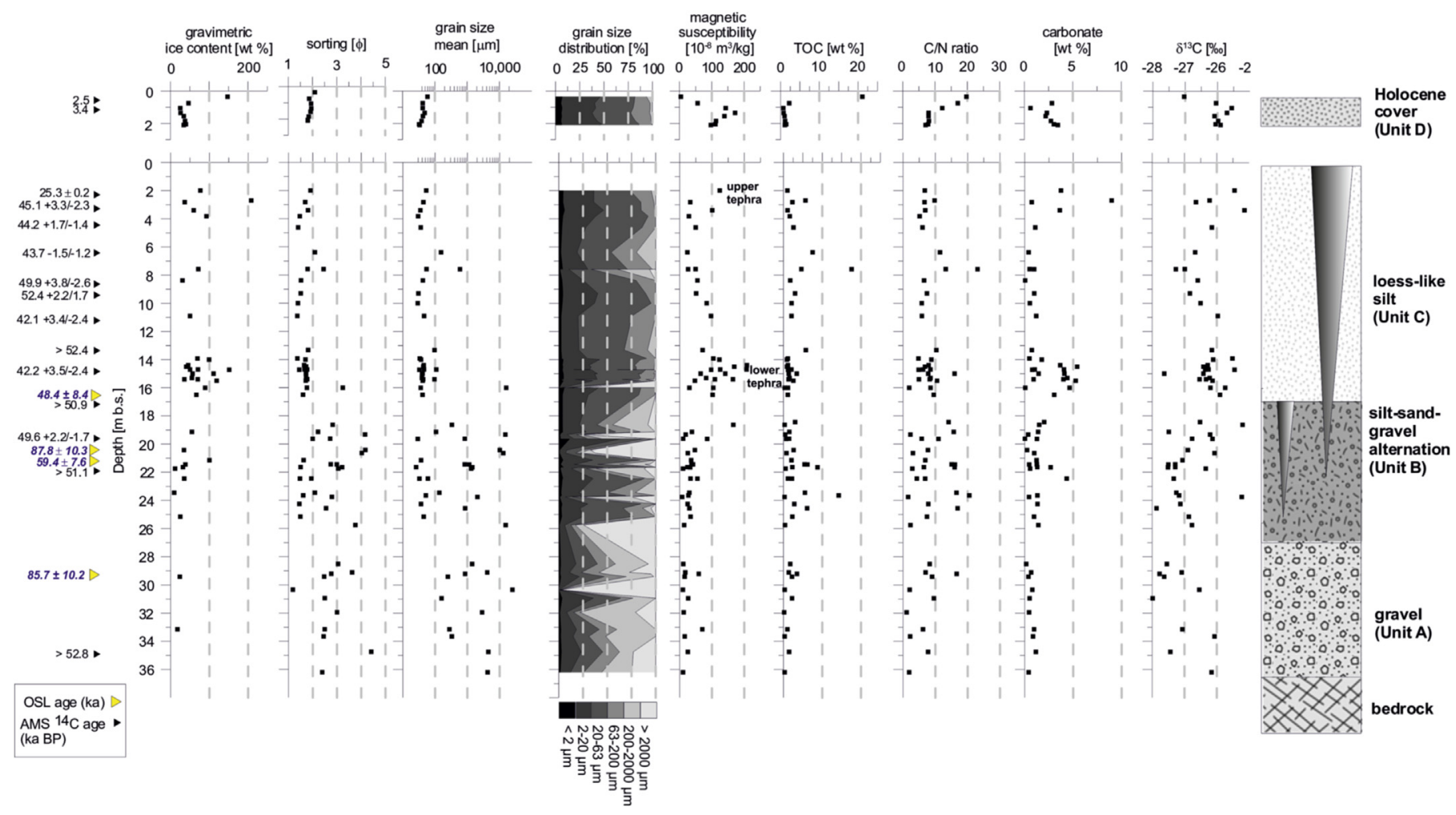

Fig. 4. Cryolithological, sedimentological, and geochronological data of VC permafrost sequence (radiocarbon data from fossil remains found in sediment samples).

Table 1

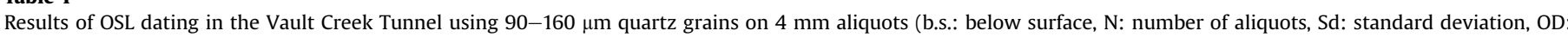

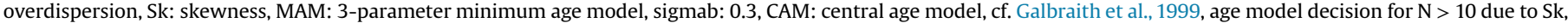
mean).

\begin{tabular}{|c|c|c|c|c|c|c|c|c|}
\hline Sample & Depth (m b.s.) & $\mathrm{N}$ & Sd (\%) & OD (\%) & Sk & Age model & Paleodose (Gy) & OSL age (ka) \\
\hline FAI-OSL-3 & 16.4 & 28 & 57.1 & 41.2 & 1.7 & MAM & $78.6 \pm 13.0$ & $54.4 \pm 10.5$ \\
\hline FAI-OSL-2 & 20.4 & 9 & 13.2 & - & - & mean & $148.8 \pm 6.8$ & $87.4 \pm 10.3$ \\
\hline FAI-OSL-1 & 21.0 & 5 & 12.7 & - & - & mean & $89.4 \pm 5.1$ & $59.4 \pm 7.6$ \\
\hline FAI-OSL-5 & 29.2 & 31 & 18.5 & 15.5 & -0.2 & CAM & $133.6 \pm 5.1$ & $93.1 \pm 10.0$ \\
\hline
\end{tabular}

RPQ) at the Leibniz Institute for Applied Geophysics (LIAG) Hannover, Germany. The application of the dating method requires two basic assumptions: negligibly small initial ${ }^{230} \mathrm{Th}$ contents and a geochemically closed system after peat formation. The first assumption can be verified due to the different chemical behavior of uranium and thorium: uranium is transported with groundwater while thorium absorbs on minerals. Uranium is incorporated into peat as it forms chemical complexes with humic acids. ${ }^{230} \mathrm{Th}$ evolves from the decay of ${ }^{234} \mathrm{U}$ in the peat over time. A violation of the first assumption can be determined by measuring ${ }^{232} \mathrm{Th}$, the naturally abundant isotope of thorium. The amount of measured ${ }^{232} \mathrm{Th}$ indicates detrital contamination of the peat with thorium, resulting in low ${ }^{230} \mathrm{Th} /{ }^{232} \mathrm{Th}$ ratios. Therefore, to correct for the admixed ${ }^{230}$ Th by the isochron technique (Ku and Liang, 1984; Schwarcz and Latham, 1989) three or more subsamples were investigated. The external reproducibility was determined by measurements of a standard NBL-112A solution (New Brunswick Laboratories Certified Reference Material) and yielded a value of $0.3 \%(1 \sigma \mathrm{SD})$.

Stable hydrogen and oxygen isotope ratios of ground ice were measured with a Finnigan MAT Delta-S mass spectrometer at the Alfred Wegener Institute in Potsdam using equilibration techniques. Ratios are given as per mil (\%o) difference from VSMOW
(Vienna Standard Mean Ocean Water), with internal $1 \sigma$ errors of less than $0.8 \%$ for $\delta \mathrm{D}$ and $0.1 \%$ for $\delta^{18} \mathrm{O}$ (Meyer et al., 2000). The results are presented in $\delta^{18} \mathrm{O}-\delta \mathrm{D}$ diagrams with respect to the Global Meteoric Water Line (GMWL: $\delta \mathrm{D}=8 \delta^{18} \mathrm{O}-10$ ), a linear correlation of global fresh surface waters (Craig, 1961). In general, the most negative values reflect the coldest temperatures. Slope and intercept in the $\delta^{18} \mathrm{O}-\delta \mathrm{D}$ diagram are valuable indicators for identifying (1) precipitation derived from the evaporation of ocean water in different regions, and (2) participation of secondary evaporation processes (Dansgaard, 1964) in signal formation. The deuterium excess $\left(\mathrm{d}=\delta \mathrm{D}-8 \delta^{18} \mathrm{O}\right)$ introduced by Dansgaard (1964) indicates kinetic (non-equilibrium) fractionation processes and is generally related to surface conditions (e.g. humidity, sea surface temperature, wind speed) in the initial moisture source region (Merlivat and Jouzel, 1979).

A standard HF technique was used for pollen preparation (Berglund and Ralska-Jasiewiczowa, 1986). One tablet of Lycopodium marker spores was added to each sample for calculating total pollen and spore concentrations following Stockmarr (1971). Water-free glycerol was used for sample storage and preparation of the microscopic slides. Pollen and spores were identified at magnifications of $400 \times$ and $1000 \times$, using pollen keys and atlases (Kupriyanova and Alyoshina, 1972, 1978; Bobrov et al., 1983; Reille, 
1992, 1995, 1998; Beug, 2004). Additionally, a number of so-called non-pollen palynomorphs, such as fungal spores and remains of algae and invertebrates, were also identified and counted when possible. These non-pollen palynomorphs can also be used to interpret past environments (e.g. Van Geel, 2001 and references therein). At least 200 pollen grains per slide were counted. In samples with extremely low concentrations up to 100 pollen grains per slide were counted. The relative frequencies of pollen taxa were calculated from the sum of the terrestrial pollen taxa. Spore percentages are based on the sum of pollen and spores. The relative abundances of reworked taxa are based on the sum of pollen and redeposited taxa. The percentages of non-pollen palynomorphs are based on the sum of the pollen and non-pollen palynomorphs, and the percentages of algae are based on the sum of pollen and algae. The Tilia/TiliaGraph software (Grimm, 1991) was used to calculate percentages and to draw the diagrams. The diagrams were zoned by a qualitative inspection of significant changes in pollen associations, pollen concentration, and the occurrence or absence of particularly indicative taxa.

Plant macrofossils were identified from a total of six sediment samples from units B and C. After freeze-drying in the lab, $200 \mathrm{~g}$ of dry sediment was dispersed in water, sieved through a $0.25-\mathrm{mm}$ mesh screen, and then air-dried. From this fraction, macrofossils of plants were picked out and identified to the lowest possible taxonomic level using an Olympus SZX 16 stereomicroscope. The identifications were based on a comparison with modern plant material accessible in the Herbarium Senckenbergianum Weimar (IQW) and Frankfurt (FR) reference collections of the Senckenberg Research Institute (Otte et al., 2011). Additionally, several identification keys and online databases were used (Hultén, 1937; Flora of North America, 1993-2007; USDA, 2013).

For testate amoeba and phytolith analysis, subsamples of about $3 \mathrm{~g}$ were first suspended in distilled water and passed through a $0.5-\mathrm{mm}$ meshed sieve to remove large masking organic and mineral particles. Then, a drop of suspension mixed with a drop of glycerin was placed on a glass slide. Testaceans were identified and counted under a light microscope at $100 \times$ and $400 \times$ magnifications (Zeiss Axioskop 2). On average, five slides were examined for each sample. In addition, the occurrence of phytoliths was recorded.

Principal component analysis (PCA) of pollen data was performed to gain insights into the underlying data structure. In particular (1) the correlation among pollen taxa with similar ecological requirements will support the ecological interpretation of the axes scores, and (2) the grouping of samples in the sample score plot will aid the extraction of zones with characteristic ecological conditions. In a second PCA, pollen PCA sample scores (axis 1 and 2), grain-size EMs, carbonate content, C/N ratios, TOC, $\mathrm{MS}$, and $\delta^{13} \mathrm{C}$ values from the same horizons were jointly analyzed to portray the data structure of the entire proxy data set. Ordinations were computed using CANOCO 4.5 and plotted using CANODRAW for Windows.

\section{Results and interpretation}

\subsection{Lithostratigraphy and geochronology}

\subsubsection{Unit A - gravel unit (36-27 m below surface (b.s.))}

About $40 \mathrm{~m}$ of Quaternary deposits overlie weathered schistose bedrock of the Precambrian or Lower Paleozoic "Birch-Creek schist". The lowermost unit A is dominated by non-sorted coarsegrained gravelly sediments containing sand lenses with woody twig and root fragments. Pebbles of $3-10 \mathrm{~cm}$ in diameter, subrounded and oriented parallel to bedding were observed (Fig. 3C). No ice wedges were detected, and the sediments contained only pore ice (structureless cryostructure). The gravimetric ice content in sand lenses amounts to about 25 wt\%. No ice content could be measured in the gravel layers. Depending on the content of plant detritus the measured TOC content varies between 0.2 and $3.5 \mathrm{wt} \%$ (Fig. 4, SOM 1). The low C/N-ratios (1-9.5) reflect the high degree of organic matter decomposition. The $\delta^{13} \mathrm{C}$ values range between -28.0 and $-26.1 \%$. Using the TIC values a carbonate content of $0.2-1.2 \mathrm{wt} \%$ was calculated. The MS of the sandy matrix in the gravel horizon varies from 10 to 26 SI. Only material from a sand lens revealed a higher value of 70 SI. One OSL sample (FAIOSL-5) from $29 \mathrm{~m}$ b.s. was dated to $93.1 \pm 10.0 \mathrm{ka}$ (Table 1$)$. An infinite radiocarbon age ( $>52.8 \mathrm{ka} \mathrm{BP})$ of a wood fragment was obtained at $34.8 \mathrm{~m}$ depth (Table 2 ).

\subsubsection{Unit B - silt-sand-gravel alternation (27-17 $\mathrm{m}$ b.s.)}

Unit B consists of irregular alternating loess-like silt, sand, and gravel layers (Fig. 3D) with peat lenses of $5-10 \mathrm{~cm}$ in diameter. Unit $\mathrm{B}$ is characterized by the occurrence of vertically oriented 0.1 - to0.4 -m-wide ice wedges. The cryostructure s mostly structureless with random separate horizontal ice bands about $0.5 \mathrm{~cm}$ thick, which were observed in silt layers. The gravimetric ice content varies between $9 \mathrm{wt} \%$ in sand and $100 \mathrm{wt} \%$ in silt. This silt-sandgravel unit is characterized by higher TOC content and stronger variation of the sediment parameters compared to unit A (Fig. 4, SOM 1). C/N ratios of organic-rich samples are higher (15-20.5), reflecting a lower degree of organic matter decomposition than in unit $A$. The $\delta^{13} \mathrm{C}$ values of -27.5 to $-25.2 \%$ are heavier than in the underlying gravel unit A. The MS varies between 7 and 85 SI without a clear relationship to the sediment type. OSL-determined sediment ages are $59.4 \pm 7.6 \mathrm{ka}$ (FAI-OSL-1), 87.4- $\pm 10.3 \mathrm{ka}$ (FAIOSL-2), and $54.4 \pm 8.4 \mathrm{ka}$ (FAI-OSL-3) at 21, 20.4, and $16.4 \mathrm{~m}$ b.s., respectively (Table 1 ). Infinite radiocarbon ages of $>51.1 \mathrm{ka}$ BP and $>50.9$ ka BP were determined for a peat lens at $21.7 \mathrm{~m}$ b.s. and an in situ mammoth bone at $16.7 \mathrm{~m}$ b.s., respectively, while a wood fragment at $19.6 \mathrm{~m}$ b.s. was dated to $49.5+2.2 /-1.7 \mathrm{ka} \mathrm{BP}$ (Table 2).

Two samples, FAI-U/Th-1 and FAI-U/Th-2, were taken in unit B for ${ }^{230} \mathrm{Th} / \mathrm{U}$ dating at $21.6 \mathrm{~m}$ and $23.6 \mathrm{~m}$ b.s., respectively (Table 3 ). Although all subsamples were taken from the inner part of the peat lenses (size about $100 \times 50 \mathrm{~cm}$ ), the concentrations of uranium and thorium vary widely. There is no reliable age information from ${ }^{230} \mathrm{Th} / \mathrm{U}$ dating.

\subsubsection{Unit $C$ - loess-like silt (17-2 $m$ b.s.)}

Unit $C$ consists of less-sorted silty fine sand containing grass roots, plant detritus, peat lenses $(3-5 \mathrm{~cm}$ in diameter), and paleosols (10-20 cm thickness). Frequent large ice wedges (up to $3 \mathrm{~m}$ visible width in its upper section) composed of numerous thin vertically oriented ice veins are visible on both walls of the tunnel and on the roof (Fig. 3A), reflecting the occurrence of a polygonal ice-wedge system. Similar observations made St.-Jean et al. (2011). The cryostructure is layered and partly lenticular. Ice belts of several $\mathrm{cm}$ in thickness occurred in $10-30 \mathrm{~cm}$ distance. They are bent upward and merged into the ice wedges, indicating their syngenetic formation (Fig. 3E). The gravimetric ice content is 21-208 wt\% (SOM 1). The ice wedges are, in part, strongly deformed, especially in the uppermost part of the tunnel sequence with an inclination of $45-50^{\circ}$ from the vertical. The sediments near the entrance tube are also deformed, perhaps due to landslides and displacements of large frozen blocks.

At a depth of $15.4 \mathrm{~m}$ b.s. and at about $2 \mathrm{~m}$ b.s. two layers of volcanic ash were observed. The lower ash layer consists of several thin light-gray laminae reflecting shallow water deposition, which likely occurred in ponding water of low-centered polygons. The light-gray layer was observed on both walls of the tunnel. The upper ash layer was observed as a light-gray 2-to-4-mm thin layer in the tunnel roof near the entrance tube (Fig. 3F). 
Table 2

Summary of all radiocarbon sediment and ice wedge samples of the Vault Creek tunnel, Fairbanks, Alaska.

\begin{tabular}{|c|c|c|c|c|}
\hline Sample ID & Depth (m b.s.) & Radiocarbon age (a BP) & Type of organic, stratigraphic position & Lab number \\
\hline FAI $4 / 7$ & 0.75 & $2505 \pm 25$ & Charcoal in paleosol horizon (unit D) & KIA 31128 \\
\hline FAI $4 / 5$ & 1.35 & $3445 \pm 35$ & Charcoal in paleosol horizon (unit D) & KIA 31127 \\
\hline FAI 3/17 & 2.00 & $20,710 \pm 120$ & Plant fragments & Beta 426293 \\
\hline FAI $3 / 20$ & 2.7 & $25,320 \pm 240$ & Peat inclusion (unit C) & KIA 31125 \\
\hline FAI- $1 / 42$ & 2.8 & $45,120+3300 /-2330$ & Grass roots (unit C) & KIA 25271 \\
\hline FAI- $1 / 40$ & 4.6 & $44,220+1700 /-1400$ & Wood, organic remains (unit C) & KIA 28133 \\
\hline FAI-IW-4 & 5.0 & $46,120+4080 /-2690$ & Organic matter in wedge ice (unit C) & KIA 25660 \\
\hline FAI-1/39 & 6.4 & $43,670+1480 /-1250$ & Plant remains (unit C) & KIA 28132 \\
\hline FAI-IW-8 & 7.5 & $>40,970$ & Organic matter in wedge ice (unit C) & KIA 25661 \\
\hline FAI- $1 / 37$ & 8.4 & $49,930+3800 /-2570$ & Wood, organic remains (unit C) & KIA 28131 \\
\hline FAI-1/36 & 9.3 & $52,390+2210 /-1730$ & Wood, organic remains (unit C) & KIA 28130 \\
\hline FAI- $1 / 34$ & 10.9 & $42,090+3410 /-2380$ & Dark brown soil (unit C) & KIA 24873 \\
\hline FAI-IW-12 & 12.0 & $34,400+4390 /-2820$ & Organic matter in wedge ice (silt unit) & KIA 25275 \\
\hline FAI-1/30 & 13.3 & $>52,440$ & Wood, plant remains ((unit C)) & KIA 28128 \\
\hline FAI- $1 / 33$ & 14.7 & $42,170+3480 /-2420$ & Plant remains (unit C) & KIA 28129 \\
\hline FAI mammoth & 16.7 & $>50,920$ & Small fragments of mammoth skull, collagen (unit B) & KIA 31124 \\
\hline FAI-1/26 & 19.6 & $49,550+2190 /-1720$ & Wood remains (unit B) & KIA 25270 \\
\hline FAI-1/19 & 21.7 & $>51,130$ & Peat lens (unit B) & KIA 24872 \\
\hline FAI- $1 / 2$ & 34.8 & $>52,790$ & Wood remains (unit B) & KIA 24871 \\
\hline
\end{tabular}

Table 3

Measured isotope activity ratios, calculated ages, and concentrations of uranium and thorium.

\begin{tabular}{|c|c|c|c|c|c|c|}
\hline Sample ID, TIMS-No & ${ }^{234} U /{ }^{238} U \pm 2 \sigma$ & ${ }^{230} \mathrm{Th} /{ }^{232} \mathrm{Th} \pm 2 \sigma$ & Age uncorrected [ka] & Age isochron [ka] & $\mathrm{U}[\mathrm{ppm}]$ & Th [ppm] \\
\hline \multicolumn{7}{|l|}{ FAI-U/Th-1 } \\
\hline 859 & $0.847 \pm 0.004$ & $0.856 \pm 0.008$ & $427+38 /-28$ & n.d. & 1.08 & 4.22 \\
\hline 860 & $0.667 \pm 0.003$ & $0.663 \pm 0.004$ & $349+10 /-9$ & n.d. & 0.99 & 5.01 \\
\hline 861 & $0.903 \pm 0.004$ & $0.915 \pm 0.013$ & $466+106 /-55$ & n.d. & 1.22 & 4.41 \\
\hline FAI-U/Th-2 & & & & $\mathrm{f}=0.0306$ & & \\
\hline 864 & $2.682 \pm 0.002$ & $2.655 \pm 0.004$ & $463+27 /-21$ & $400+19 /-16$ & 2.90 & 3.32 \\
\hline 865 & $2.383 \pm 0.004$ & $2.332 \pm 0.006$ & $356+17 /-14$ & $327+17 /-15$ & 0.47 & 0.63 \\
\hline 866 & $7.496 \pm 0.004$ & $7.318 \pm 0.008$ & $376+20 /-17$ & $363+23 /-19$ & 4.01 & 1.66 \\
\hline 867 & $2.809 \pm 0.003$ & $2.762 \pm 0.007$ & $391+28 /-22$ & $357+25 /-20$ & 0.52 & 0.58 \\
\hline
\end{tabular}

The major element composition of glass shards (Table 4) shows that the $\mathrm{Na}_{2} \mathrm{O}, \mathrm{Al}_{2} \mathrm{O}_{3}$ and $\mathrm{SiO}_{2}$ contents of both tephra are in the same range. The lower tephra is discriminable from the upper tephra by higher $\mathrm{MgO}$, $\mathrm{CaO}$ contents, lower $\mathrm{K}_{2} \mathrm{O}, \mathrm{Fe}_{2} \mathrm{O}_{3}$ and $\mathrm{Cl}$ contents, the occurrence of $\mathrm{P}_{2} \mathrm{O}_{5}$ and the absence of $\mathrm{MnO}$ and $\mathrm{CU}_{2} \mathrm{O}$.

The organic matter in silty sand deposits (1-3 wt\% TOC) is more strongly decomposed ( $\mathrm{C} / \mathrm{N}=5$ to 8.5$)$ than in organic-rich peat inclusions and peaty paleosols (5-17 wt\% TOC; C/N of 10-23). The $\delta^{13} \mathrm{C}$ values ( -27.6 to $-25.1 \%$ ) are in the same range as in the underlying unit B (Fig. 4, SOM 1). The MS values (24-207 SI) are generally higher than in the lower units $A$ and $B$; the highest values are related to the ash layers (Fig. 4). The geochronological record of unit $\mathrm{C}$ consists of three AMS ${ }^{14} \mathrm{C}$ ages from organic matter included in ice wedges (Fig. 5) and nine AMS ${ }^{14} \mathrm{C}$ dates from plant remains in the sediment (Fig. 4, Table 2). There are two infinite ages of $>53.4 \mathrm{ka}$ BP (at $16.7 \mathrm{~m}$ b.s.) and $>40.9 \mathrm{ka}$ BP (at $7.5 \mathrm{~m}$ b.s.). Most of the radiocarbon ages cover the range between $52.4+2.2 /-1.7$ ka BP and $42.17+3.5 /-2.4$ ka BP but lack a significant age-depth relationship. Three younger ages were derived from an ice wedge sample at $12 \mathrm{~m}$ b.s. $(34.4+4.4 /-2.8 \mathrm{ka} \mathrm{BP})$, from a sediment sample at $2.7 \mathrm{~m}$ b.s. $(25.3 \pm 0.24 \mathrm{ka} \mathrm{BP})$ and from the upper tephra layer at $2 \mathrm{~m}$ b.s. $(20.7 \pm 0.12 \mathrm{ka} \mathrm{BP})$.

\subsubsection{Unit $D$ - Holocene cover (2-0 $m$ b.s.)}

The uppermost unit $\mathrm{D}$ is composed of sediments accessible in the auger hole (Fig. 3B) near the tunnel entrance. The site was located about $2 \mathrm{~m}$ above the entrance level. At this location deposits above an ice wedge were studied between 2.3 and $0 \mathrm{~m}$ b.s. The uppermost part of this weakly bedded silty sand has been affected by pedogenesis. Unit D was primarily separated because of its late-
Table 4

Average major element composition of glass particles from the upper and the lower tephra layer.

\begin{tabular}{|c|c|c|c|c|c|c|}
\hline & \multicolumn{3}{|c|}{ Upper tephra (FAI 3/17) } & \multicolumn{3}{|c|}{ Lower tephra (FAI 3/1) } \\
\hline & Mean & STD & $\mathrm{n}$ & Mean & STD & $\mathrm{n}$ \\
\hline $\mathrm{Na}_{2} \mathrm{O}$ & 3.33 & 0.99 & 37 & 3.34 & 0.67 & 28 \\
\hline $\mathrm{MgO}$ & 0.38 & 0.15 & 37 & 0.82 & 0.46 & 28 \\
\hline $\mathrm{Al}_{2} \mathrm{O}_{3}$ & 14.06 & 0.86 & 37 & 14.98 & 0.76 & 28 \\
\hline $\mathrm{SiO} 2$ & 75.14 & 1.57 & 37 & 75.02 & 1.75 & 28 \\
\hline $\mathrm{P}_{2} \mathrm{O}_{5}$ & - & - & - & 0.55 & 0.13 & 2 \\
\hline $\mathrm{Cl}$ & 0.15 & 0.03 & 33 & 0.04 & 0.02 & 7 \\
\hline $\mathrm{K}_{2} \mathrm{O}$ & 2.82 & 0.64 & 37 & 1.89 & 0.39 & 28 \\
\hline $\mathrm{CaO}$ & 1.32 & 0.37 & 37 & 1.81 & 0.49 & 28 \\
\hline $\mathrm{TiO}_{2}$ & 0.39 & 0.36 & 37 & 0.29 & 0.06 & 28 \\
\hline $\mathrm{MnO}$ & 0.13 & 0.03 & 8 & - & - & - \\
\hline $\mathrm{Fe}_{2} \mathrm{O}_{3}$ & 2.35 & 0.67 & 37 & 1.80 & 0.92 & 28 \\
\hline $\mathrm{Cu}_{2} \mathrm{O}$ & 0.15 & 0.02 & 6 & - & - & \\
\hline
\end{tabular}

Holocene age of $3.4 \mathrm{ka}$ BP at $1.35 \mathrm{~m}$ b.s. and $2.5 \mathrm{ka}$ BP at $0.75 \mathrm{~m}$ b.s. (Table 2). No cryostructure could be observed (structureless) and the gravimetric ice content is relative low (25-50 wt\%) besides the uppermost sample (147 wt\%). However, its sedimentological records are very similar to those of the silty fine-sand unit $\mathrm{C}$ below it (Fig. 4, SOM 1). Only the $\mathrm{C} / \mathrm{N}$ ratio is higher (7-20), indicating a lower degree of organic matter degradation in the Holocene and modern soil layers compared to that seen in unit C.

\subsection{Stable isotope ground-ice records}

The stable isotope signature of 25 ice wedges (145 individual 

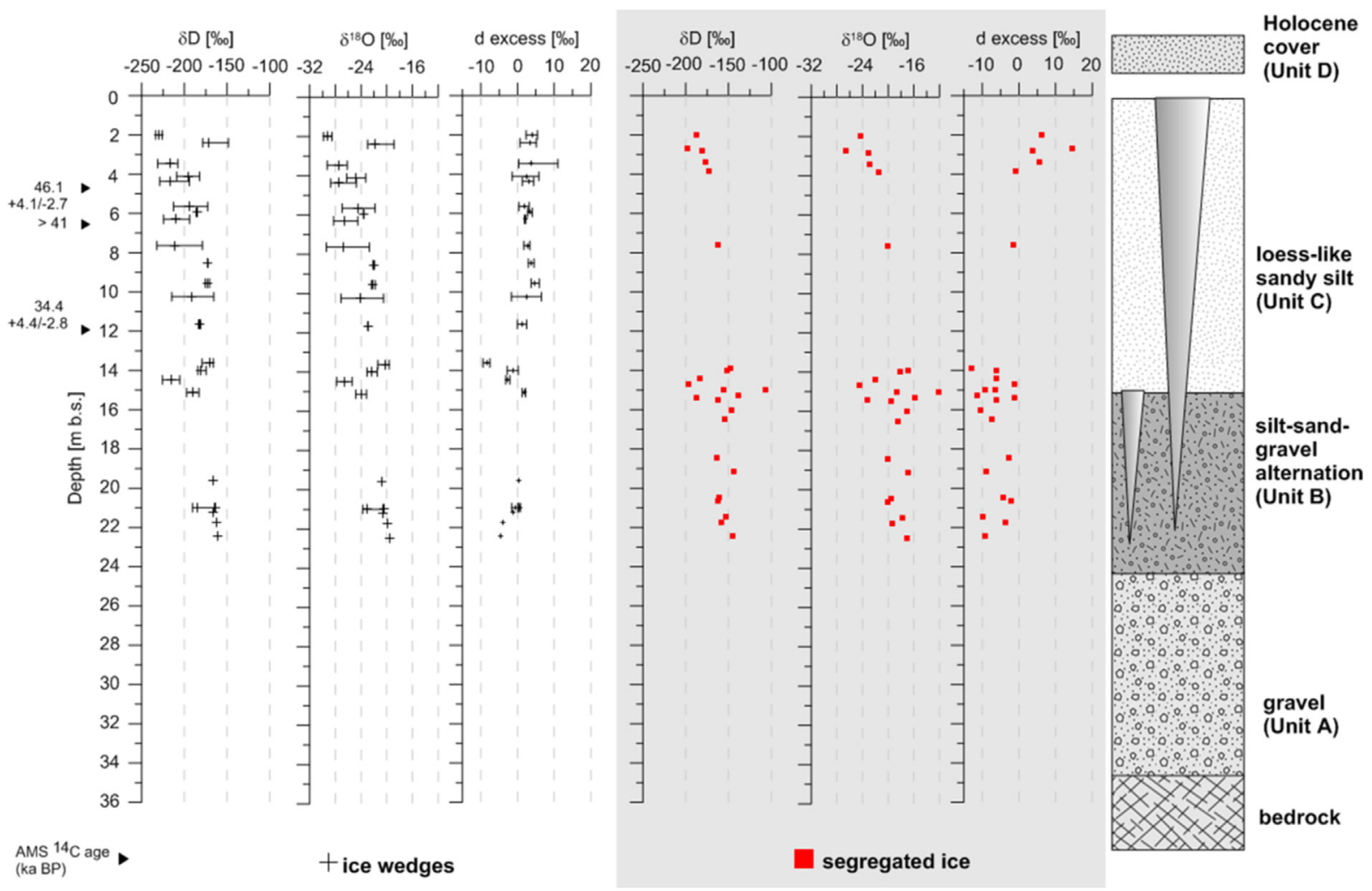

Fig. 5. Stable water isotope signature of ice wedges and segregated ice of the VC permafrost sequence (radiocarbon ages of plant remains found in ice wedges).

samples) shows a weak trend from heavier ratios at about $21 \mathrm{~m}$ b.s. (mean $\delta^{18} \mathrm{O}$ : $-20.5 \%$; mean $\delta \mathrm{D}$ : $-163.8 \%$; d excess: $0.5 \%$ ) to lighter ratios at about $2 \mathrm{~m}$ b.s. (mean $\delta^{18} \mathrm{O}$ : $-29.2 \%$; mean

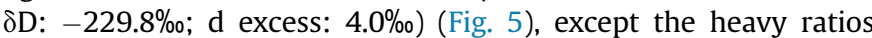
(mean $\delta^{18} \mathrm{O}$ : $-21.9 \%$; mean $\delta \mathrm{D}$ : $-171.8 \%$; d excess: $3.2 \%$ ) of a probably-Holocene ice wedge at $2.4 \mathrm{~m}$ b.s. near the tunnel entrance. The d-excess values vary between -9.4 and $11 \%$. The regression in a $\delta^{18} \mathrm{O}$ - $\delta \mathrm{D}$-isotope plot (Fig. $6 \mathrm{~A}$ ) exhibits a slope of 7.4, which is somewhat lower than the GMWL slope of 8.0 but higher as the slope the Fairbanks local meteorological water line $\left(\delta \mathrm{D}=6.7 \times \delta^{18} \mathrm{O}-21.589\right)$ according to Griffing (2011).

The stable isotope signature of segregated ice was only determined in 23 samples in which the ice content was high enough to yield sufficient melt water for analysis. The results display a highly variable isotopic composition $\left(\delta^{18} \mathrm{O}\right.$ : -26.6 to $-12.2 \%$; $\delta \mathrm{D}$ : -198.3 to $-107.2 \%$; d excess: $-12.9-14.5 \%$ ). The isotopic composition of segregated ice is heavier at about $22 \mathrm{~m}$ b.s., varies strongly at 16 to $14 \mathrm{~m}$ b.s., and is the lightest at the top of the silt horizon at about $2 \mathrm{~m}$ b.s. (Fig. 5). The segregated-ice slope of 6.4 in a $\delta^{18} \mathrm{O}-\delta \mathrm{D}-$ isotope plot (Fig. 6B) suggests secondary isotope fractionation during segregated-ice formation.

\subsection{Paleoecological records}

\subsubsection{Pollen and non-pollen palynomorphs}

The oldest pollen spectra of pollen zone I (PZ-I, 36.2 to $27 \mathrm{~m}$ b.s.) within unit A are dominated by Picea, Betula, Alnus, Ericales, and Cyperaceae pollen and Sphagnum and Lycopodium spores (Fig. 7). The spectra indicate that spruce forest with birch, larch, and some shrubby alder dominated at the site during the PZ-I interval. Ericaceous plants probably occurred between the dwarf shrubs. Rather large amounts of Sphagnum spores and Cyperaceae pollen may reflect paludification of the forest and presence of mires in the
Vault Creek Valley. The revealed pollen spectra unambiguously point to temperate (wet and warm) environmental conditions, similar to Holocene ones.

The PZ-II (27 to ca. $17.5 \mathrm{~m}$ b.s.) correlates with unit B and is characterized by higher pollen contents of Picea (up to 75\%) and Cyperaceae (up to 60\%) and a decrease in Ericales if compared to PZ-I. Pollen assemblages reflect the fact that spruce forest with some birch dominated at the site during the PZ-II interval. Single Larix pollen grains most likely indicate that some larches grew around the study site. Single hemlock (Tsuga) and fir (Abies) pollen grains were also found. Sphagnum moss with heathers and sedges was also broadly present in the local vegetation.

PZ-III (ca. 17.5 to $8 \mathrm{~m}$ b.s.), representing the lower part of unit C, is also rich in Picea and Cyperaceae pollen reflecting the spruce forest that grew in the area. Well-preserved pollen of hemlock and fir are consistently present in the spectra, however, these pollen grains are probably reworked from Tertiary sediments. In addition, obviously reworked (mineralized) Pinaceae and single Tilia pollen support the assumption of a reworked origin of the relatively thermophilic taxa. Large amounts of Glomus spores and Cichoriaceae pollen point to active erosion processes around the site. The disappearance of Sphagnum spores and Ericales pollen in PZ-III may also point to better drainage of the area during the interval, resulting in the disappearance of typical mire habitats. The climate conditions were still relatively wet and warm, similar to those in the previous time interval.

PZ-IV (ca. 8 to $3 \mathrm{~m}$ b.s.) corresponds to the middle part of unit C. The lower part of PZ-IV is characterized by an increase in Ericales, Betula, and Alnus pollen and Sphagnum spores while Picea pollen content is significantly decreased. This most likely reflects some deterioration of the climate conditions at the beginning of the PZ-IV interval that caused drastic hydrological changes, i.e. paludification of the site. However, the area remained forested by birch, spruce, 

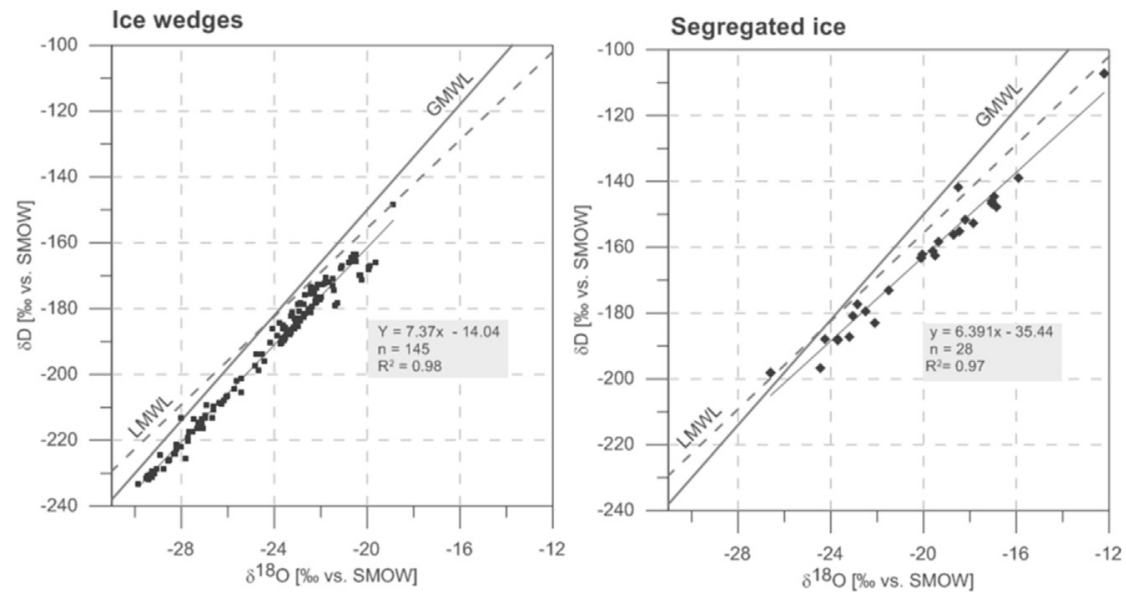

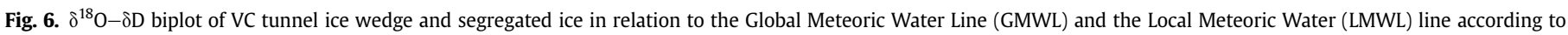
Yoshikawa and Hinzman (2003).

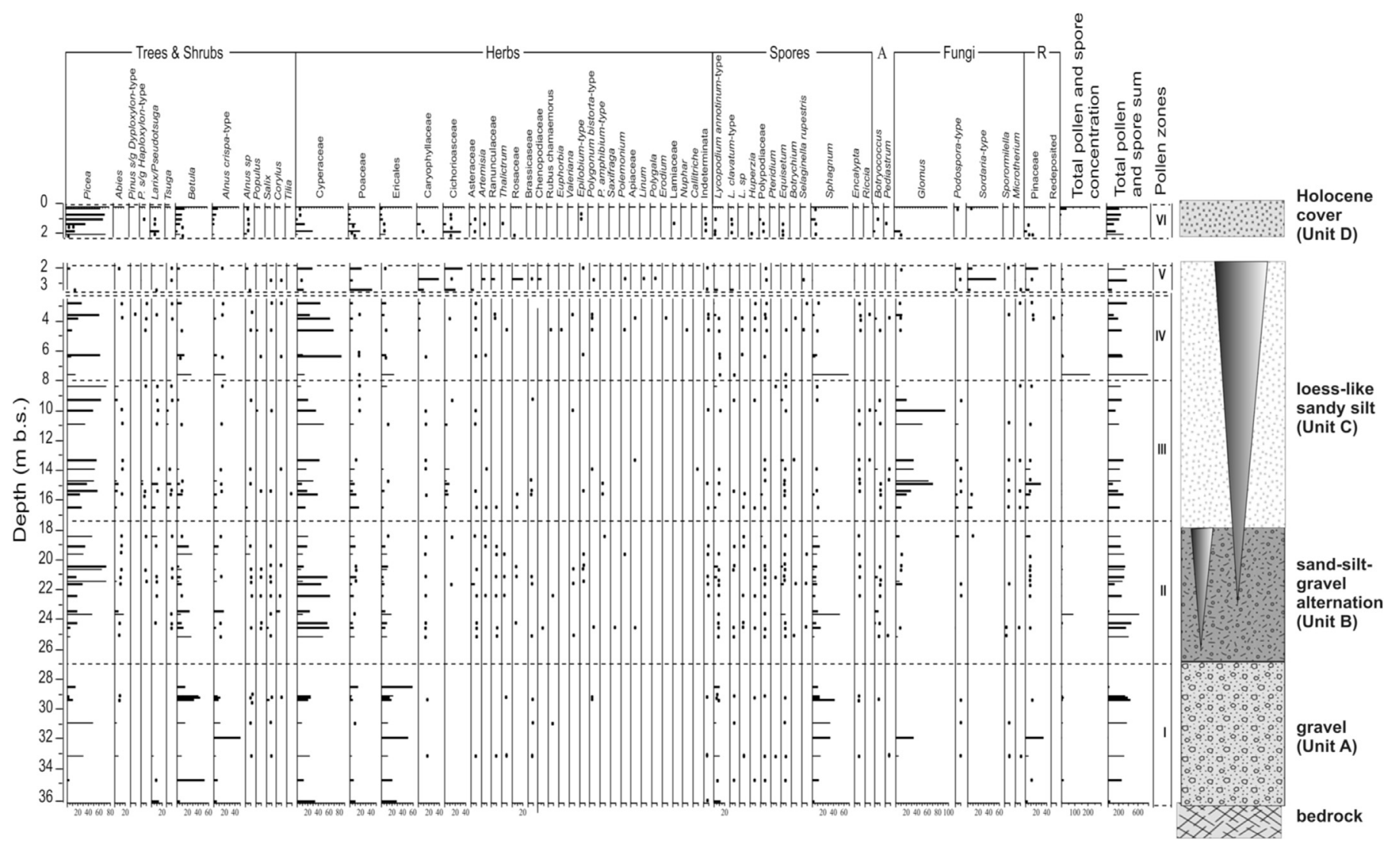

Fig. 7. Pollen record from the VC tunnel sequence (A - algae, $\mathrm{R}$ - redeposited).

and alder. An increase of Picea pollen contents in the sediments above about $6 \mathrm{~m}$ b.s. shows that climate conditions again became warmer. Numerous Cyperaceae pollen also indicate that local environmental conditions became wet again. The single hemlock and fir pollen grains most likely are of reworked origin as described for PZ-III. Decrease of the tree pollen contents in PZ-IV reflects some deterioration of the climate conditions. However, spruce still dominated the local vegetation around the site.

Pollen spectra from the upper part of unit C (PZ-V, ca. 3.5 to $2 \mathrm{~m}$ b.s.) reflect a treeless environment. The radiocarbon age of $25,320 \pm 240$ a BP (FAI 3/20) points to the late Wisconsin age of the interval. Herb communities with Caryophyllaceae, Poaceae, Cichoriaceae, Artemisia, and Rosaceae dominated the local vegetation. The single hemlock and fir pollen grains are certainly of reworked origin. A peak of coprophilous Sordaria spores in this zone is indirect evidence of numerous grazing animals in the study area. Climate conditions were extremely dry and cold during this time.

The upper most PZ-VI (ca. 2 to $0 \mathrm{~m}$ b.s.) is dominated by Picea, Betula, Alnus, Ericales, and Cyperaceae pollen. These pollen assemblages indicate that spruce forest with birch and some shrub alder dominated during the interval. The dominance of herb taxa 
(Cyperaceae, Poaceae, Cichoriaceae) and of Larix pollen and Glomus spores may reflect some climate deterioration at the beginning of PZ-VI and an episode of disturbed environments most likely connected with forest fire events.

Principal component analysis (Fig. 8) of pollen data indicates that taxa such as Sphagnum and some shrubs (Salix, Betula, Ericaceae) that are indicative of or tolerant to moist habitats are positively correlated with the first axis. Accordingly, all samples of unit $A$ and some samples of unit B accumulated when the local conditions were wet and unstable and local water-tolerant vegetation were widespread. In contrast, most trees (Picea, Larix, Pinus, Tsuga) and also some steppe elements such Artemisia and Poaceae are negatively correlated with the first axis. This indicates that the river was not active at the sample location when units $C$ and D accumulated, but the site was covered by more-or-less-open forestssteppe (unit C) or northern forests similar to today (unit D).

\subsubsection{Plant macrofossils}

Content and preservation of plant macrofossils differed considerably within the studied sediment sequence (SOM 3). The sample with the highest macrofossil content (FAI 1/24) taken from a peat inclusion at $21.44 \mathrm{~m}$ b.s. and the sample from a peat lens (FAI $1 / 19$ ) at $21.65 \mathrm{~m}$ b.s. represent the lithostratigraphical unit B (PZ-II), the lowermost stratum containing identifiable plant remains. Although considerably differing in abundance, diversity, and preservation of plant macrofossils, both samples provide the same environmental indication; the existence of a boreal forest interspersed with wetlands largely resembling the modern local vegetation. The peat inclusion (sample FAI 1/24) was dominated by spruce remains, mainly black spruce (Picea mariana) as is indicated by the short length, only $7-10 \mathrm{~mm}$, of the preserved needles. Also the other detected tree species such as gray alder (Alnus incana ssp. tenuifolia), birch (Betula cf. neoalaskana), and tamarack (Larix laricina) are regular constituents of the modern vegetation assemblage in the study area. The presence of Tsuga or Abies, whose pollen was recorded by palynological analyses, is not confirmed by plant macrofossils. Most of the detected trees, namely Picea mariana, Alnus incana ssp., and Larix laricina, are characteristic of wet habitats like lakeshores, muskegs, bogs, and peatlands. Also numerous nutlets of wetland sedges (Carex sect. Phacocystis) including water sedges (Carex aquatilis) and the seeds of other wetland plants (Comarum palustre, Ranunculus lapponicus, Hippuris vulgaris, Epilobium palustre) indicate the existence of a small water body or muskeg at the bottom of the VC Valley when unit B was deposited. The other plants found in both samples represent the shrub or herb taxa typical of wet taiga habitats: Betula glandulosa/ nana subsp. exilis, Cornus canadensis, Moehringia laterifolia, Empetrum nigrum, Chamaedaphne calyculata, Vaccinium vitis-idaea, Geum macrophyllum, Viola sp., and Pentaphylloides fruticosa.

Sample FAI 1/33 taken from the lower part of the loess-like sandy silt unit $C$ at $14.7 \mathrm{~m}$ b.s. (PZ-III) differs fundamentally from the unit B macrofossil record. Only a very few poorly preserved plant remains could be found representing tundra steppe vegetation and very dry conditions. Among them, Phlox hoodii is characteristic of sagebrush and mountain grassland communities and occurs at dry, open, rocky, gravelly, or sandy sites (Gucker, 2006).

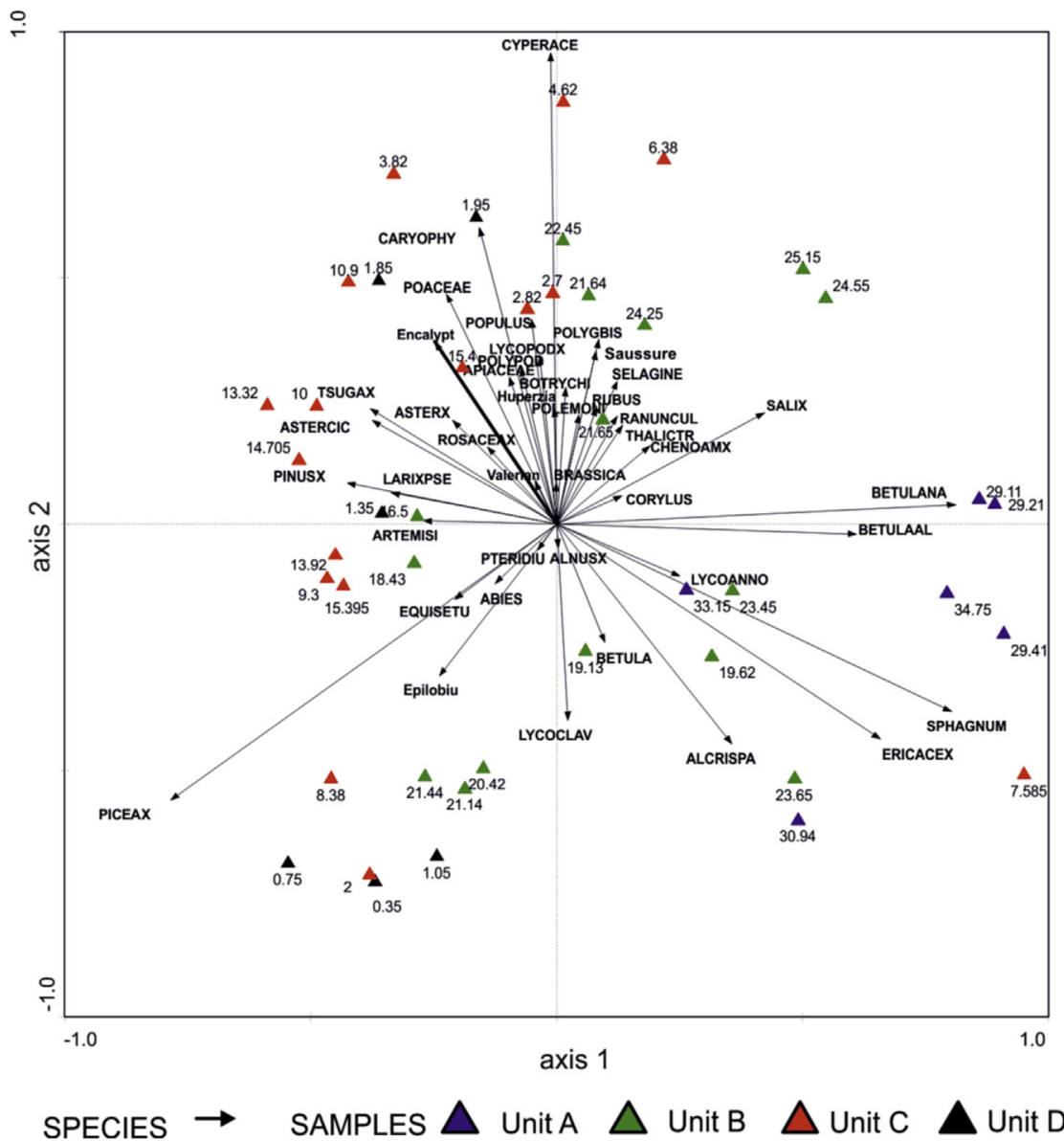

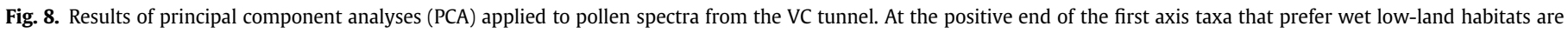
presented; taxa that prefer dry upland habitats are seen at the negative end. Arrows indicate the positioning of the taxa and symbols refer to sample depth b.s. 
The plant is not able to withstand shading and therefore avoids forest vegetation. The other tundra-steppe indicator in the assemblage is Kobresia, which is characteristic of dry, open grasslands and tundra habitats that are snowless in winter. Both taxa together clearly indicate a cold stage with cool and very dry climate conditions unsuitable for trees.

A peat inclusion sampled at $7.58 \mathrm{~m}$ b.s. (FAI 1/38a) in the middle part of unit $C$ contains only sparse identifiable plant remains of spruce (Picea), wetland sedges (Carex sect. Phacocystis), and high northern buttercup (Ranunculus hyperboreus) that reflect again a wet coniferous forest resembling modern vegetation around Fairbanks. That indication applies also to a peat inclusion at $6.38 \mathrm{~m}$ b.s. (FAI 1/39) radiocarbon-dated to $43+4.1 /-2.7 \mathrm{ka} B P$ (Table 2 ), which is much richer in species. The paludification suggested by PZ-III pollen assemblages can be confirmed by the increase of wetland sedges (Carex sect. Phacocystis, several hundred nutlets) including water sedge (Carex aquatilis) and spruce muskeg sedge (Carex lugens). During the time of deposition, the dwarf shrubs Betula glandulosa/nana subsp. exilis, Empetrum nigrum, Salix sp., and Ledum palustre ssp. decumbens occurred in the shrub understory in spruce forest; the existence of forest vegetation is indicated by spruce needles.

In a silt layer at $2.82 \mathrm{~m}$ b.s. (FAI 1/42) in the uppermost part of unit $\mathrm{C}$ radiocarbon-dated to about $45.1+3.3 /-2.3$ ka BP (Table 2) only Betula glandulosa/nana subsp. exilis, Luzula sp., and Carex sect. Phacocystis were detected, indicating again wet habitats under a boreal climate. Even though fossils of tree species were not detected, their existence cannot be excluded due to the incompleteness of preserved plant remains in this sample.

Altogether, over most of the studied sequence of units B and C, boreal coniferous forests interspersed with muskegs similar to modern vegetation existed at the study site.

\subsubsection{Testate amoebae and phytoliths}

Shell-bearing amoebae (testaceans) were found in twelve samples, mostly from peat lenses in both lower coarse-grained units $A$ and $B$ and organic-rich silt and peaty lenses in the loesslike sandy silt unit C (Fig. 9, Table 5). The amoeba assemblage includes 32 taxa (species and subspecies) that belong to the soileurybiontic (E + soil), calciophilic (Ca), hydrophilic (W), and sphagnophilic (Sph) ecological groups. The density of rhizopod shells is low (one to a few tens of shells per gram) in most of the samples.

Only three soil-eurybiontic species (Centropyxis constricta v. minima, C. sylvatica, C. sylvatica v. minor) were found in a coarsegrained sand lens at about $29.4 \mathrm{~m}$ b.s. (unit A). Morphological forms of the minor type can be regarded as an adaptation to dry soil conditions, and the sample itself as a paleosol; this conclusion is also supported by the occurrence of grass phytoliths.

Soil-eurybiontic species Centropyxis constricta v. minima, Centropyxis aerophila v. minor, C. sylvatica v. minor, and Cyclopyxis eurystoma v. parvula were identified in peaty unit B deposits at 24.5 and $21.6 \mathrm{~m}$ b.s. The minor morphometric forms can be seen as an indicator of dry or relatively dry conditions. Phytoliths of herbaceous plants were also found in these samples. Similar amoeba associations indicating dry paleosol conditions were found in unit $C$ peat lenses at 15.4, 13.3, and $7.6 \mathrm{~m}$ b.s. In addition, Plagiopyxis minuta was found at 9.3 and $8.4 \mathrm{~m}$ b.s. in unit C; this organism is more common in soil habitats.

The shell density and species diversity was rather high (28 taxa from all ecological groups) in the sample from a peat lens at $6.38 \mathrm{~m}$ depth (Fig. 9, Table 5). The tecamoebae assemblage is dominated by soil-eurybiontic species (71.7\%). The calciophilic Centropyxis plagiostoma sensu lato with the variations typica, major, and minor constitutes $15.1 \%$ of the total findings. Sphagnobiotic species from two groups distinguishable by their relationship to humidity were also found in this sample. The first group (Trigonopyxis arcula, Assulina muscorum) prefers dryer oligotrophic bogs. The second group (Centropyxis discoides, $C$. elongata, Heleopera rosea, $H$. petricola $v$. amethystea, $H$. petricola $v$. humicola, Nebela lageniformis, Difflugia globularis) occurs in moister habitats. Phytoliths of herbaceous plants found in the samples also indicate temporary waterlogging. Thus, the testate amoeba record implies an oligomesotrophic Sphagnum bog with variable seasonal water conditions probably connected to a shallow permafrost table.

Rare findings of the soil-eurybiontic Centropyxis constricta v. minima and Cyclopyxis eurystoma v. parvula in the uppermost part of unit C (at $3.82 \mathrm{~m}$ b.s.) point to dry soil conditions while numerous shells of seven soil-eurybiontic taxa (Table 5) and the sphagnobiotic Arcella arenaria v. compressa at $2.82 \mathrm{~m}$ b.s. reflect a more favorable soil environment than that indicated in the previous samples.

\section{Discussion}

\subsection{Geochronology of the VC tunnel record}

Units A and B dated by OSL to four ages $(93.1 \pm 10.0 \mathrm{ka}$, unit A; $87.4 \pm 10.3 \mathrm{ka}$ to $54.4 \pm 10.5 \mathrm{ka}$, unit $\mathrm{B}$ ) as well as infinite radiocarbon dates ( $>52.8$ to $>50.9 \mathrm{ka} \mathrm{BP}$ ) from both units point to their deposition during the early Wisconsin to mid-Wisconsin. The two older OSL ages of unit B (sample FAI-OSL-1: $59.4 \pm 7.6 \mathrm{ka}$ and sample FAI-OSL-2: $87.4 \pm 10.3 \mathrm{ka}$; Table 1) may be considered as maximum age estimates due to their small data sets and corresponding modeling uncertainty. Moreover, the 90-160 $\mu \mathrm{m}$ quartzgrain fraction necessary for OSL dating was not sufficiently available in silty deposits. Hitherto, there has been no systematic luminescence dating studies of permafrost deposits to estimate the influence of permafrost-specific properties and processes such as the fixing and release of radioactive compounds by organic matter and ground ice. The in situ enrichment of quartz and feldspar grains by frost weathering (Schwamborn et al., 2012) in fractions relevant for luminescence dating and the pressure effect of pore and segregation ice on quartz and feldspar grains have also not been studied so far. Dating permafrost by luminescence approaches that reach beyond the limits of the radiocarbon method is in progress; however, careful interpretation of such dating results contributes to chronostratigraphic studies.

Another method used to date 'old' material employs ${ }^{230} \mathrm{Th} / \mathrm{U}$ radioisotope disequilibria in frozen peat. Based on previous experience (Schirrmeister et al., 2002; Wetterich et al., 2008, in press) two peat lenses were sampled from unit B. The sample FAI-U/Th-1 shows ${ }^{230} \mathrm{Th} /{ }^{232} \mathrm{Th}$ activity ratios that plot as a very narrow cluster in the Rosholt-type I diagram. The ratios do not fulfill the requirements of the isochron method. The calculated single ages cannot be corrected for the detrital contamination; such a correction is highly needed as indicated by the low values of $0.6-0.9$ for ${ }^{230} \mathrm{Th} /{ }^{232} \mathrm{Th}$ activity ratios. Accordingly, no geochronological age can be gained from this analysis. The plot of the FAI-U/Th-2 data set (SOM 2) indicates open system behavior. Uranium activities are shifted towards the field of slow accumulation. The age of the sampled peat remains unclear. The observed trend may be explained either by further uranium uptake from percolating water and slope processes, or by any thawing processes in the peat that would mobilize the uranium more strongly than the thorium, and to some extent fractionate ${ }^{234} \mathrm{U}$ and ${ }^{238} \mathrm{U}$. Additionally, changes in redox conditions can easily cause such effects, because ${ }^{234} \mathrm{U}$ is more mobile than ${ }^{238} \mathrm{U}$. A further suggestion of open system behavior is given by the contents of uranium and thorium.

Unit $C$ was radiocarbon dated to between $>52.4$ and $20.7 \pm 0.12$ ka BP. The dates do not show a strong age-depth relationship and 

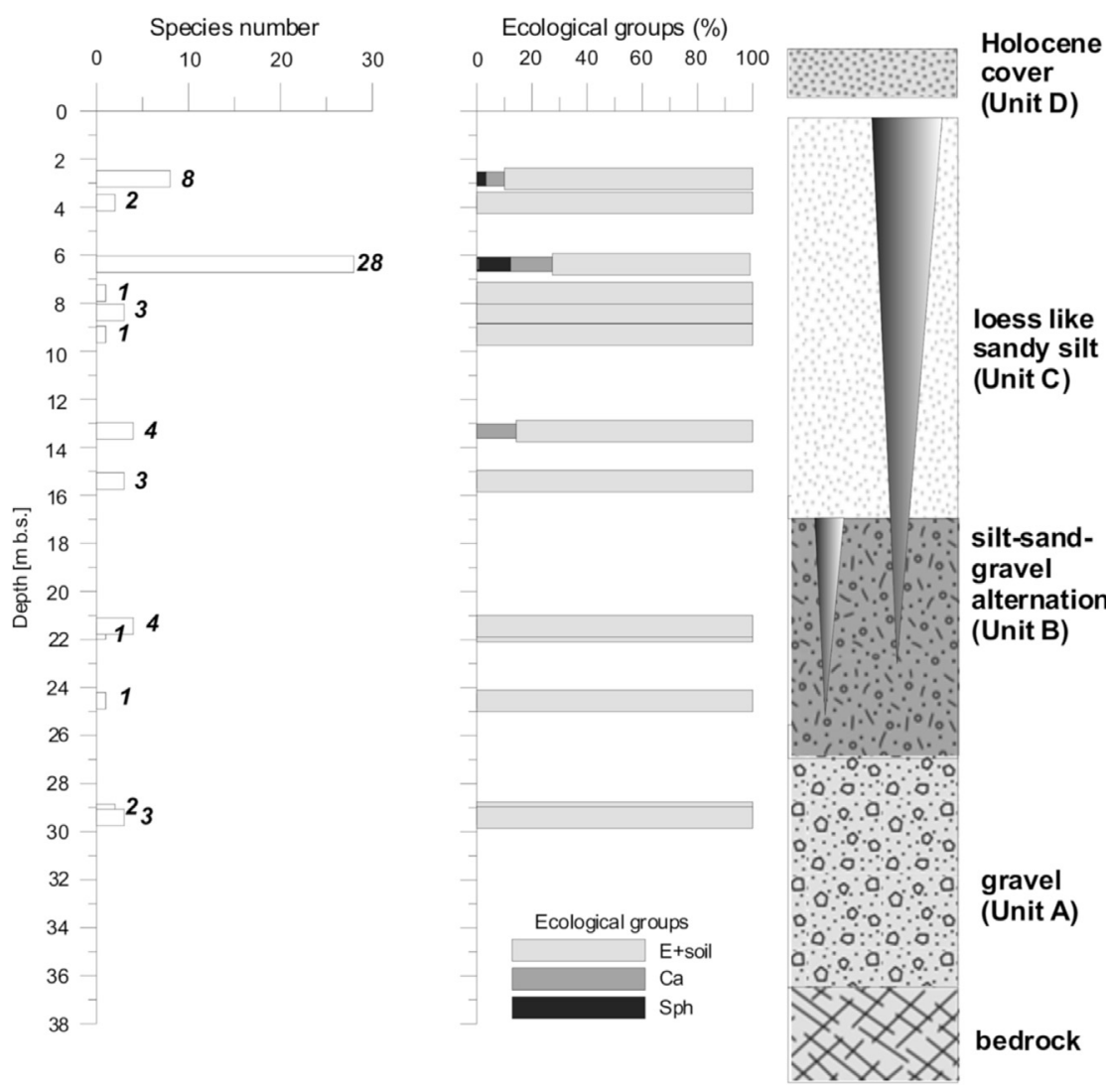

Fig. 9. Tecamoebae record, species number, and distribution of ecological groups.

display, because of the high ages, relatively large error bars. The uppermost date of unit $\mathrm{C}$ points to discordant deposition during late Wisconsin.

According to its lithostratigraphical position and the surrounding infinite radiocarbon dates and one OSL date of $48.4 \pm 8.4 \mathrm{ka}$ the lower ash layer could be interpreted as Dome Tephra in the Fairbanks area, which dates to $>55.9$ ka BP (Muhs et al., 2003) or as Variegated Tephra (VT) (Jensen et al., 2008, 2011) OSL-dated to $77.8 \pm 4.1 \mathrm{ka}$ (Table 6$)$. The radiocarbon dating of $20,710 \pm 120$ a BP (25,285 to 24,540 cal a BP)of plant fragments directly picked from the upper ash layer sample at $2 \mathrm{~m}$ b.s. supports the interpretation of the upper ash layer as Dawson Tephra according to Westgate et al., 2000 who wrote that "... Dawson tephra is younger than 22,300 years, but older than 11,620 years ...". However, according to the major element composition of glass shards neither the lower nor the upper tephra found in the VC tunnel could be classified in the Alaskan tephra chronology (Fig. 10). Both are especially characterized by higher $\mathrm{SiO}_{2}$ contents end lower $\mathrm{Na}_{2} \mathrm{O}$ contents (Table 4). More detailed studied of the glass shards are needed to better classify both tephra.

Unit D was sampled in an additional auger hole drilled above the tunnel. Radiocarbon dates at 0.75 and $1.35 \mathrm{~m}$ b.s. exhibit late Holocene ages of $2505 \pm 25$ a BP and $3445 \pm 35$ a BP, respectively. The relationship to underlying unit $C$ is discordant. Lateglacial and early to middle Holocene deposits were not detected in this study.

Although three different dating methods were applied, the geochronological results remain incomplete. This is mainly due to (1) the radiocarbon dating method reaching its analytical limits in mid-Wisconsin deposits, (2) OSL dating being limited because the necessary $90-160 \mu \mathrm{m}$ grain size is rarely available in loess-like silts, and (3) the precondition of a closed system for ${ }^{230} \mathrm{Th} / \mathrm{U}$ dating of peat did not exist. However, in general the geochronological results support the stratigraphic classification of the VC permafrost sequence in the MIS 5a (late Sangamon) to MIS 1 (late Holocene) periods, including large parts of the Wisconsin glacial period (MIS 4 to MIS 2). The studied sequence in the VC tunnel is somewhat older than the permafrost sequence of the CRREL Fox tunnel (Hamilton et al., 1988).

\subsection{Synthesis of paleo-proxy records}

The end-member modeling of the grain size results (Fig. 11) revealed two robust EMs and one residual member. EM1 is dominated by coarse-grained mostly sandy material probably of fluvial origin. EM2 is composed of well-sorted material dominated by medium to coarse-grained silt peaking at about $40 \mu \mathrm{m}$ probably originating from a loess-like accumulation by eolian processes or eolian re-transportation of primary loess deposits. The residual member represents poorly sorted material indicating reworking of material of various sources such as occurring during permafrost and cryosol formation. The plot of the relative contributions of the two EMs and the residual member (Fig. 10) indicates that unit A was dominated by fluvial accumulation, in unit B fluvial and eolian layers are intermixed, unit $C$ was almost solely formed by loess(like) sediments, and unit D is mainly composed of reworked sediments.

The stable isotope signature of ice wedges (mean $\delta^{18} \mathrm{O}:-29.2$ to $-20.5 \%$; mean $\delta \mathrm{D}$ : -229.8 to $-163.8 \%$; mean d excess: $0.5-4.0 \%$ ) is in the same range of late Pleistocene ice-wedge data in the CREEL Fox tunnel (Douglas et al., 2011; Lachniet et al., 2012), in the Barrow permafrost tunnel (Meyer et al., 2010) in Barrow, and on the Yukon Coastal Plain in the western Canadian Arctic (Fritz 
Table 5

Species list of Tecamoebae.

\begin{tabular}{ll}
\hline Species & Ecological group \\
\hline Centropyxis aerophila & Soil-eurybiontic (E + soil) \\
C. aerophila v. minor & \\
C. cassis & \\
C. constricta & \\
C. constricta $v$. minima & \\
C. orbicularis & \\
C. sylvatica & \\
C. sylvatica v. minor & \\
Cyclopyxis kahli & \\
C. eurystoma v. parvula & \\
Plagiopyxis bathystoma & \\
P. declivis & \\
P. minuta & \\
P. penardi & \\
Schoenbornia humicola & \\
Arcella arenaria v. compressa & \\
Trigonopyxis arcula & \\
C. discoides & \\
C. elongata & \\
Heleopera rosea & \\
H. petricola v. amethystea & \\
H. petricola $v$. humicola & \\
Nebela lageniformis & \\
N. sp. & \\
Assulina muscorum & \\
Euglyphasp. & \\
Difflugiellasp. & \\
C. plagiostoma & \\
C. plagiostoma major & \\
Difflugia globularis & \\
\hline
\end{tabular}

plant macrofossil record found in six samples reflect rather similar environments. The presence of well-preserved, relatively heavy and, therefore, not easily airborne hemlock (Tsuga) and fir (Abies) pollen in PZ-II to PZ-IV led to the initial assumption that these trees grew occasionally around or not far from the site in very wet mire habitats. However, nowadays these taxa grow in Alaska only in the rather humid coastal areas, where winter temperatures range from -13 to $-3{ }^{\circ} \mathrm{C}$ and summer temperatures range from 12 to $17{ }^{\circ} \mathrm{C}$; mean annual precipitation of the last 50 years reaches $400 \mathrm{~mm}$ (WMO 702720, Anchorage/Elmendorf, AFB). Therefore, it is difficult to conclude that these taxa grew in the study area during the late Pleistocene. In addition, these rare finds of hemlock and fir pollen are not supported by plant macrofossils. To our knowledge, both taxa are described neither in interstadial nor in interglacial paleobotanical records from Interior Alaska (Bigelow et al., 2007; Bigelow, 2013; Wooller et al., 2011). Therefore, in contrast to previous interpretation of these pollen taxa in Meyer et al. (2008) an interglacial (MIS 5e) record is excluded and these thermophilic pollen are considered to be reworked from older sediment, e.g. from Tertiary deposits where both taxa are known to have occurred in Alaska (Ager and Brubaker, 1985). Similar interpretations of Tsuga pollen findings at Palisades (Yukon River, Interior Alaska) are given by Reyes et al. (2010a).

The paleobotanical interpretations of one sample (FAI 1/33) taken at $14.7 \mathrm{~m}$ b.s. and radiocarbon-dated to $42,170+3480 /-2420$ a BP (Table 2) differ strongly. The pollen assemblages reflect the presence of spruce forest while the plant macrofossils indicate cold and dry tundra steppe conditions. A possible explanation is that the few and poorly preserved plant remains found in only one sample are possibly not representative. Nevertheless, the occurrence of Glomus spores and Cichoriaceae pollen indicating erosion and the disappearance of Sphagnum spores and Ericales pollen reflect

Table 6

Stratigraphic relevant volcanic tephra of interior Alaska and the surroundings.

\begin{tabular}{|c|c|c|c|}
\hline Tephra & Age (ka) & Site/area & Reference \\
\hline Dawson tephra & 24 & Klondike area (Yukon) & Froese et al., 2002, 2006 \\
\hline Dom tephra & $>55.9$ & Fairbanks area & Muhs et al., 2001, 2003, 2008 \\
\hline Variegated (VT) tephra & $77.8 \pm 4.1$ & $\begin{array}{l}\text { Halfway House road cut, } \\
\text { Gold hill } \\
\text { Fairbanks area }\end{array}$ & Preece et al., 2011; Jensen et al. 2011; Berger 2003, Muhs et al., 2003 \\
\hline Halfway House tephra & $76.7-80.0$ & $\begin{array}{l}\text { Halfway House road cut, } \\
\text { Gold hill } \\
\text { Fairbanks area }\end{array}$ & Muhs et al., 2003, Berger 2003 \\
\hline SD Tephra & & Halfway House road cut & Berger 2003 \\
\hline Sheep Creek tephra (SCt) & $\begin{array}{l}190 \pm 20 \\
\sim 80\end{array}$ & $\begin{array}{l}\text { Fairbanks area } \\
\text { Yukon area }\end{array}$ & Westgate et al., 2008 \\
\hline $\begin{array}{l}\text { Old Crow tephra } \\
(\mathrm{OCt})\end{array}$ & $140 \pm 10$ & Fairbanks area & Preece et al., 2011; Westgate et al., 1990 \\
\hline
\end{tabular}

et al., 2012). The signature is comparable to late Pleistocene interstadial (MIS 3) ice wedges studied by Meyer et al. (2000, 2002a, b) in eastern Siberia. The apparently "warmer" signals $\left(\delta^{18} \mathrm{O}\right.$ : about $-20.5 \%$, $\delta \mathrm{D}$ about $-165 \%$ ) from the lower part in Unit B originate from small ice wedge of only several decimeters in width, that probably are treated by exchange process with the surrounding frozen deposits. The values fit rather well with the isotope signature of segregated ice from the same depth (see Fig. 5). An increase of stable isotope values of about $6 \%$ at ice wedge contacts is described in high-resolution ice-wedge studies (e.g. Opel et al., 2010: Meyer et al., 2010) and was also observed in ice wedges of the Fox Tunnel by Lachniet et al. (2012).

In general, the VC late Sangamon and early, middle, and late Wisconsin pollen assemblages (42 samples) and the exemplary temporary changes of site-specific landscape and hydrological conditions.

Despite the low number of individuals, the preservation of testate amoebae, highly sensitive to transport processes (Bobrov et al., 2004), proves in-situ formation and preservation of the peaty deposits. The dominating eurybiontic and soil ecological group points to repeated cryopedogenesis and reflects stable surface conditions.

The synopsis of sedimentological and palynological data presented in a second PCA-plot (Fig. 12) shows a clear differentiation of unit $A$ and $C$. While unit $A$ is controlled by moist pollen associations (pollen 1) and the coarse-grained fraction of endmember 1 (EM1), unit $C$ is characterized by dry pollen associations (pollen 2 ), the fine-grained fraction of endmember 2 (EM2), higher carbonate 

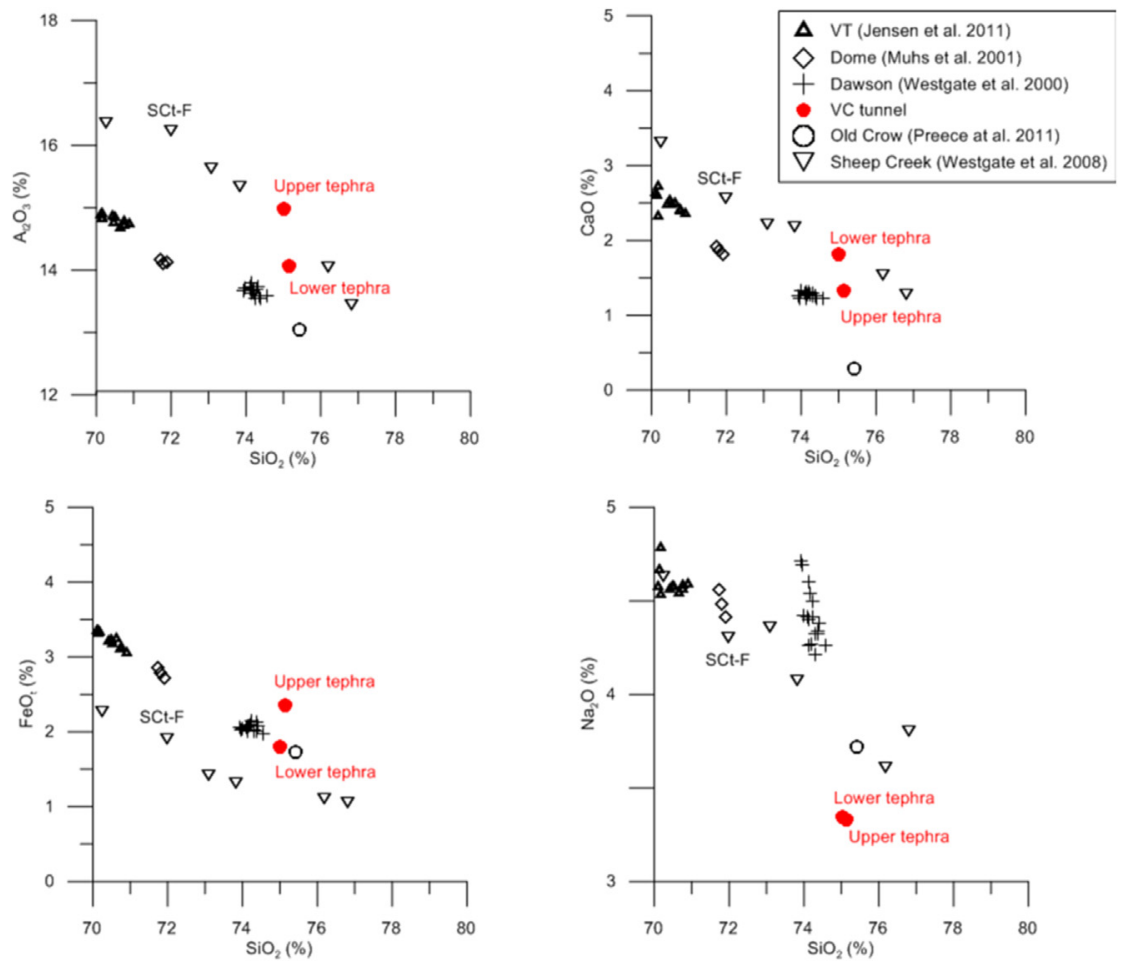

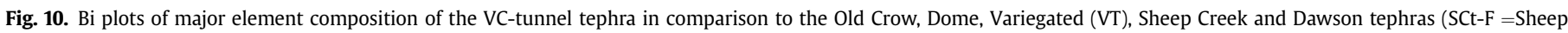
Creek Tephra Fairbanks).

content and higher magnetic susceptibility. The higher variability of sediment and pollen data in unit $C$ is also shown in Fig. 12. Finally, unit $\mathrm{D}$ is characterized by high values of the residual grainsize member that probably reflects different transport processes due to sediment reworking. The organic matter parameters (TOC, C/ $\mathrm{N}, \delta^{13} \mathrm{C}$ ) show no correlation that could be explained by the stratigraphy of units A to D. However, the anti-correlation of the $\mathrm{C} / \mathrm{N}$ and $\delta^{13} \mathrm{C}$ data sets is interpreted as pattern of organic matter decomposition.

\subsection{Landscape and environmental dynamics}

The study of the VC tunnel sediments and ground ice contributes to the Interior Alaskan late Quaternary paleoenvironmental history. Péwé (1975, p. 42) wrote that "In Wisconsinan time, additional loess was deposited on the uplands, and much loess was re-transported to valley bottoms to form a carbonaceous, fetid, perennially frozen deposit, locally termed, muck'. This valleybottom facies of Wisconsin age loess is $3-46 \mathrm{~m}$ thick and contains abundant vertebrate and plant fossils". According to Péwé (1975) creeks in Interior Alaska contain gravel that is characteristically angular and poorly sorted. Most of the gravel represents solifluction material transported over short distances by stream action. In valley bottoms the gravel deposits are discordantly overlain by re-transported loess rich in organic remains and containing many ice wedges $0.3-3 \mathrm{~m}$ wide, which probably penetrate the entire thickness of this horizon (unit C) and as much as $10 \mathrm{~m}$ long. Therefore, the cryolithostratigraphical results from the VC tunnel expose a classical valley-bottom facies of creek valleys in Interior Alaska that in the Vault Creek Valley consists of younger fan gravel, re-transported Wisconsin silt, and re-transported Holocene silt (Fig. 13).

The revealed landscape dynamics of the valley bottom started with a continuous creek transporting and accumulating the coarse- grained material of unit A during the late Sangamon period. Then the water current decreased and the creek meandered across the valley bottom during the early Wisconsin and the beginning of the middle Wisconsin, as evidenced by the alternating peaty and fineand coarse-grained deposits of unit B. First ice wedge polygons were formed in the floodplain in dryer sites of the meander belts. A general change of the landscape and accumulation conditions took place during the middle Wisconsin with the formation of loess-like unit $C$ and associated large ice wedges. The bottom of the VC Valley was covered by fine-grained sandy silt and shaped by polygonal patterned ground with ponding water and/or peat growth in polygon centers.

The Loess-like unit $C$ is radiocarbon-dated to between 50 and 40 ka BP. However, these dates do not exhibit a strong age-depth relationship and display, because of the high ages, relatively large error bars. Hence, a question arises: How do these ages of around 50-40 ka BP correlate with the temperate indications derived from interpreting the pollen data of PZ-II and PZ-III? The frequent occurrence of ice wedges in loess-like unit $C$ proves that winters must have been cold enough for frost cracking and summers were not warm enough to melt the ground ice.

A more temperate middle Wisconsin around 40-30 ka with interstadial climate conditions has been described at various sites in Interior Alaska (e.g. Wooller et al., 2011 and references therein). Thaw unconformities in the Fox Tunnel (reflecting the so-called "Fox thermal event") have been dated to 35 to $30 \mathrm{ka}$ BP (Hamilton et al., 1988). In northwest Canada, a middle Wisconsin Boutellier non-glacial interval with temperatures similar to present temperatures has been dated to between 38 and $30 \mathrm{ka}$ BP (Schweger and Janssens, 1980). Three ${ }^{14} \mathrm{C}$ dates from ice wedges fall into this time interval (two from the Fox Tunnel [Hamilton et al., 1988] and one from the VC tunnel [present study]), confirming that in the region, frost cracking was active at that time. For about the same interval, temperatures similar to the present 


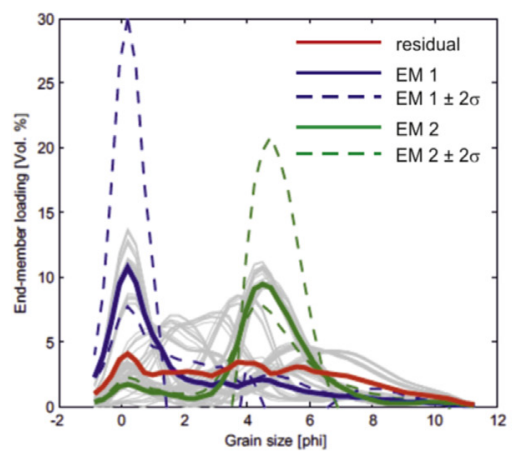

Endmember modelling
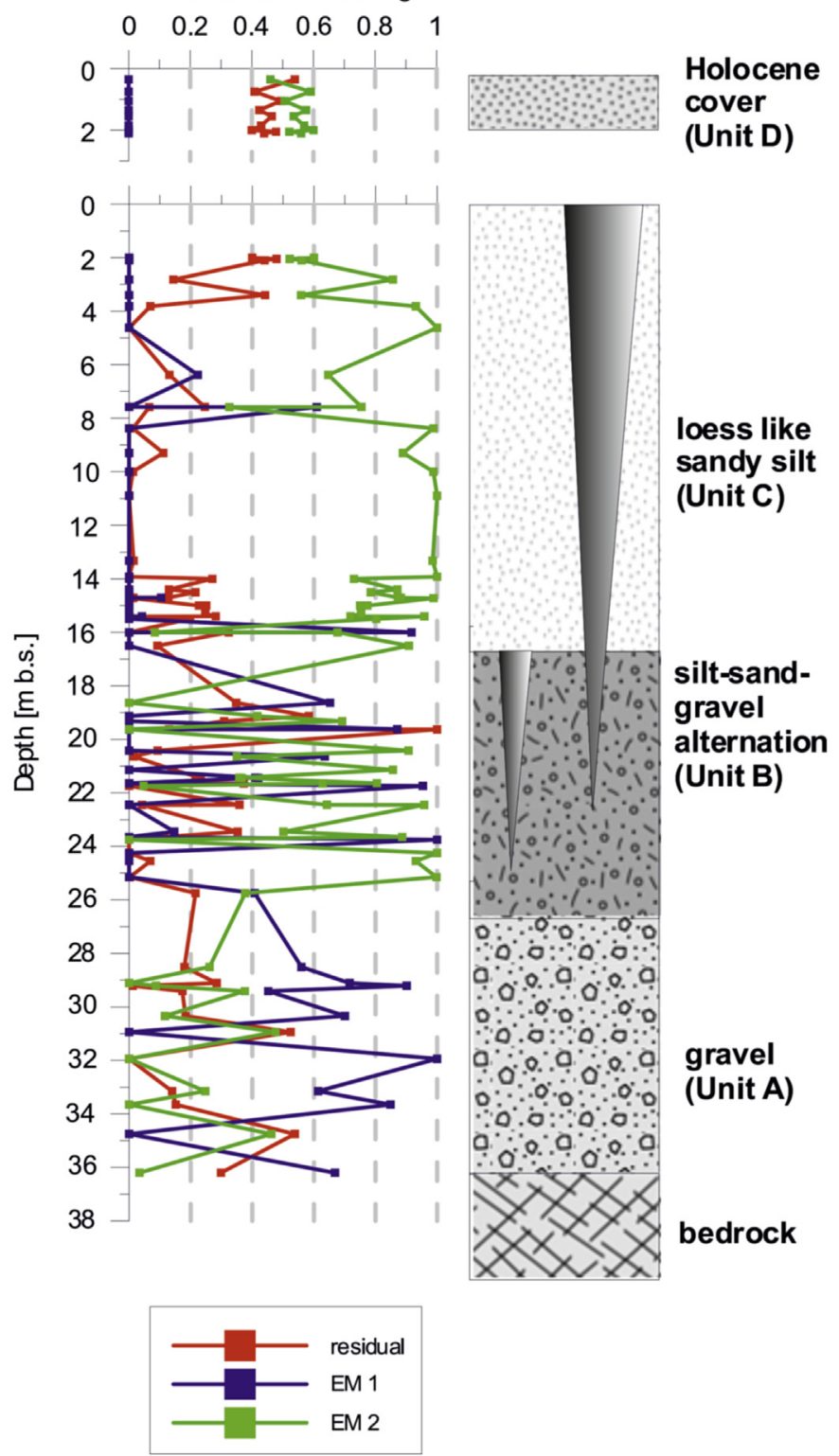

Fig. 11. Results of end-member modeling of grain-size data. Upper panel: Endmember loading along grain-size fraction for the final two endmembers (EM 1 - coarse fraction, EM 2 - loess fraction) and the residual member. (Grey lines indicate all endmember loadings from model runs with a varying number of endmembers.) Lower panel: Portion covered by the single endmembers and residual member along depth.

temperatures were derived by pollen analysis for a sediment record of the Isabela Basin, near Fox (Matthews, 1974). In addition, Anderson and Lozhkin (2001) determined an earlier warmer interval from 60 to $50 \mathrm{ka}$ BP for the Fairbanks area. The recorded occurrence of forested areas in Interior Alaska during the late Sangamon to middle Wisconsin period is in contrast to plant and insect macrofossil studies from ground squirrel middens in the Klondike area by Zazual et al. (2011), who stated a steppe-tundra ecosystem for the early Wisconsin period.

The top of the VC tunnel sequence reveals a part of the climate history around $25 \mathrm{ka}$ BP. Pollen data indicate a characteristic cold and glacial climate and treeless tundra-steppe environment. This indication fits rather well with records of Zazula et al. (2006) from similar dated samples below the Dawson tephra studied in the Klondike area. The lightest isotopic composition in ice wedges (also in segregated ice) points to the coldest winter conditions. Therefore, the records from the uppermost part of loess-like unit $\mathrm{C}$ belong to the late Wisconsin glacial period. These records show clearly that in the VC Valley, loess accumulation continued at least until 25 ka BP, while at the Fox Tunnel, a hiatus was observed between about 30 and 14 ka BP (Hamilton et al., 1988).

The youngest part of the regional history was derived from samples taken in an auger hole and dated to the second part of the Holocene, when peat accumulation took place, ice-wedge growth was common, and the climate was relatively wet and warm according to pollen assemblages and the stable isotope composition of ice wedges (Meyer et al., 2008).

The present permafrost record is related to general accumulation in a valley position and large-scale climatic variations since MIS 5a, while changes in local hydrology are additionally reflected in MIS 2 and MIS 1 records of the VC data set.

This study sheds light on the poorly studied temperate interval in middle Wisconsin times in Interior Alaska. The observation that trees grew close to the site allows the interpretation that a small forest existed in the VC area due to locally temperate conditions; this forest survived through Wisconsin times. Péwé (1975, p. 86) quoted Hopkins $(1970,1972)$ that "scattered spruce probably persisted in isolated creek bottoms in central Alaska, inasmuch as spruce wood occurs in the frozen re-transported silt of Wisconsinan age in the Fairbanks area".

\subsection{Regional and trans-regional significance}

In Beringia there is only a little known about the late Sangamon, early Wisconsin, and the early period of the middle Wisconsin, which are the periods primarily seen in the VC permafrost sequence. According to Berger (2003) the loess profile of Gold Hill trench $1 \mathrm{~b}$ TL-dated to about 80 to $27 \mathrm{ka}$ and the upper $10 \mathrm{~m}$ of the Halfway House profile dated to between 120 and 10 ka cover almost the same period as the VC sequence. However, no paleoecological data from the MIS 5a-to-4 period are available and the MIS 4 period is marked as "record missing" in the review paper of Muhs et al. (2003). This gap is covered by the VC record.

While the last Interglacial (MIS 5e) of Beringia is quite well documented in East Siberia (e.g. Wetterich et al., 2009; Kienast et al., 2008, 2011; Andreev et al., 2011), Alaska (e.g. Hamilton and Brigham-Grette, 1991; Edwards et al., 2003; Muhs et al., 2003; Reyes et al., 2010a), and the Yukon Territory (e.g. Matthews at al., 1990; Schweger and Matthews, 1991), and the MIS 3 has been studied at numerous sites during the last decades (e.g. Anderson and Lozhkin, 2001; Kanievskiy et al., 2011; Schirrmeister et al., 2011; Wetterich et al., 2014), the period between MIS5 and MIS3 is less recorded in the Beringia.

According to Schirrmeister et al. (2013) and quotations therein, eolian processes have dominated the accumulation of Yedoma deposits in the North American Arctic and sub-Arctic. In our study the unit $\mathrm{C}$ loess deposits could be considered as a specific type of Yedoma deposit formed in small valleys during the late Pleistocene. 


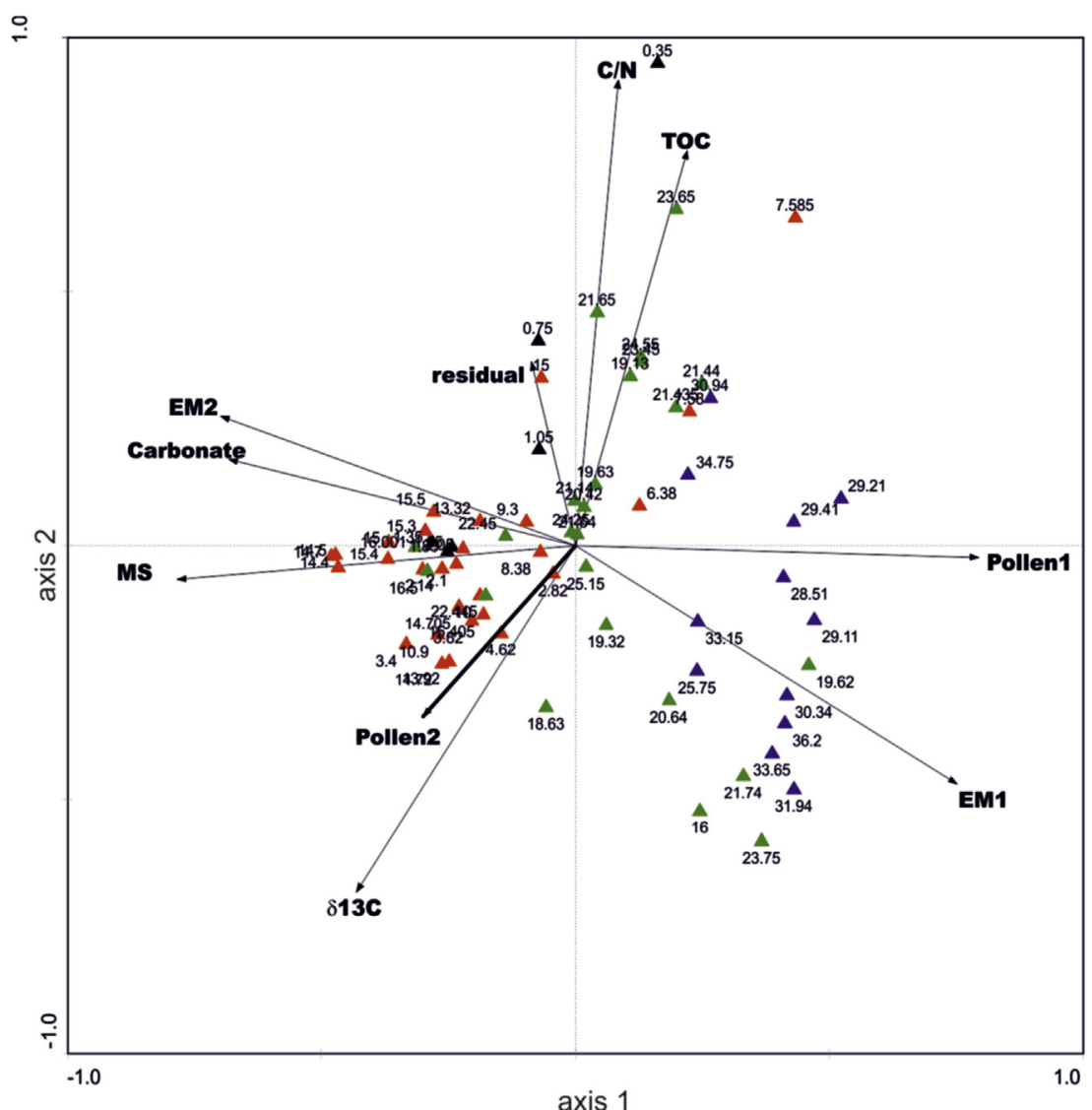

\section{SPECIES $\rightarrow$ SAMPLES $\Delta$ UnitA $\Delta$ Unit B $\Delta$ Unit $\mathrm{C} \Delta$ Unit D}

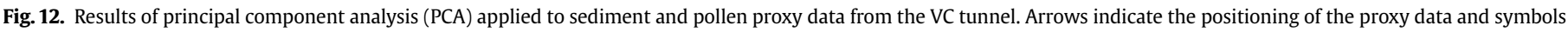
refer to sample depth b.s.

The organic carbon content of the VC Yedoma deposits has already been used in estimates of circumpolar permafrost organic carbon stocks (Strauss et al., 2013).

\section{Conclusions}

The late Quaternary record of the VC tunnel near Fairbanks spans more than $90 \mathrm{ka}$ and indicates varying environmental conditions, from rather fluvial (gravel) to eolian (loess) deposition, corresponding to the Wisconsin valley-bottom facies in Central Alaska according to Péwé (1975).

Based on complementary geochronological, cryolithostratigraphical, and paleoecological data sets there are strong arguments that the studied permafrost sequence in the VC tunnel is younger

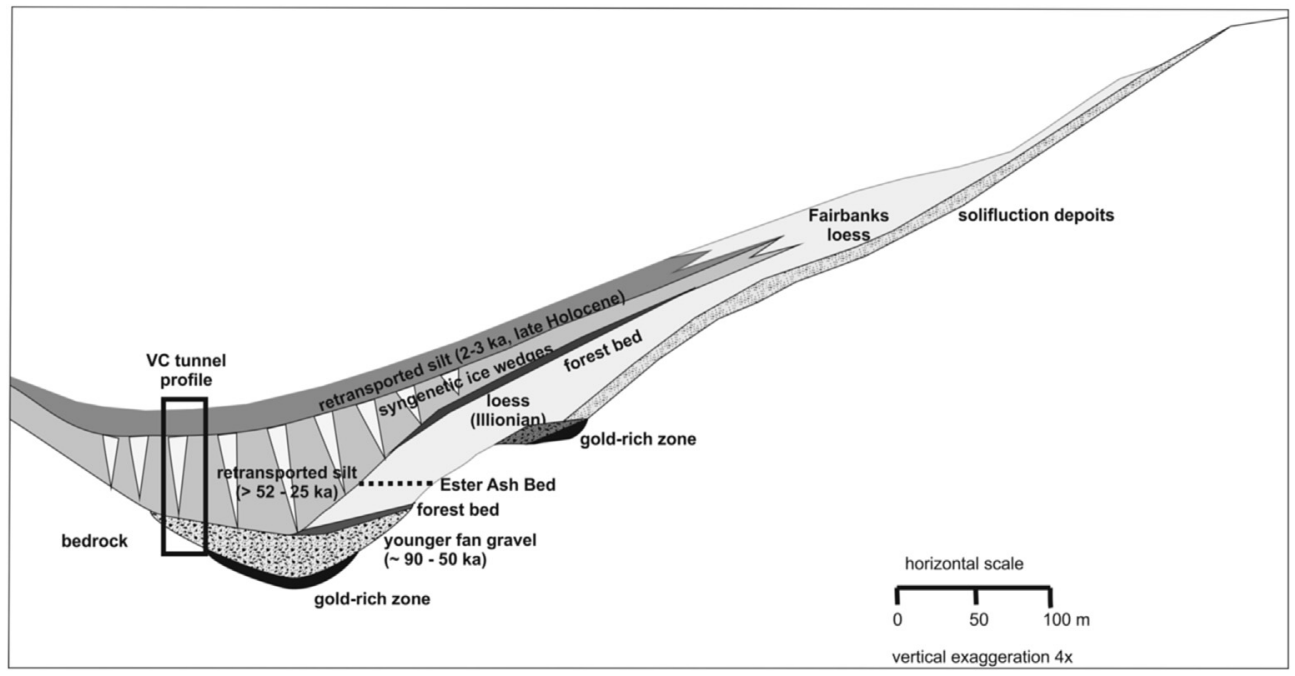

Fig. 13. Integration of the VC-tunnel sequence into the schematic composite cross section of a creek valley in Central Alaska (modified according to Péwé, 1975). 
than the Illinoian (300-130 ka) or the older MIS 11 (500 ka) stages.

Fluvial activity was intensive in the VC area during the early Wisconsin, leading to the deposition of a $17.5 \mathrm{~m}$ thick fluvial gravel sequence. Climate conditions were warm and wet, similar to Holocene conditions, according to paleobotanical proxy data.

AMS ${ }^{14} \mathrm{C}$ dates indicate that silt accumulation and ice-wedge growth took place in the vicinities of the VC Valley from 50 to 40 ka BP (MIS 3) to at least $25 \mathrm{ka} \mathrm{BP}$ (MIS 2). A rather warm phase with spruce-dominated forest vegetation occurred in Interior Alaska during the MIS 3.

Climate deterioration is evident at around $25 \mathrm{ka} \mathrm{BP}$, when the climate was colder than today and a treeless tundra-steppe environment prevailed as indicated by pollen and ice wedge stable isotope geochemistry.

A late Holocene sediment cover on top of the permafrost sequence reflects environmental conditions similar to the conditions of modern Interior Alaska.

\section{Author's contributions}

LS and HM initiated and designed the present study, and wrote the paper with contributions from the other co-authors. LS and $\mathrm{HH}$ sampled and described the material cryolithologically. LS provided sedimentological and biogeochemical data and interpretation. MF provided OSL dating and interpretation. MS provided ${ }^{230} \mathrm{Th} / \mathrm{U}$ dating and interpretation. AA provided pollen data and interpretation. FK provided plant macrofossil data and interpretation. $A B$ provided tecamoebae data and interpretation. HM provided ground ice data and interpretation. UH provided the multivariate statistics and interpretation. SW contributes to the data interpretation and synthesis. All co-authors contributed to the final discussion of obtained results and interpretations.

\section{Acknowledgement}

We thank Kenji Yoshikawa for the initiation of the studies in the VC tunnel and the great support during fieldwork and the afterward intense discussion of analytical results. We thank Mr. Sam Skidmore, the owner of the VC tunnel, for field support and valuable suggestions. The authors thank the lab team of the AWI in Potsdam for general assistance during sample preparation and analysis, especially Ute Bastian, Antje Eulenburg, and Lutz Schoenicke. The work of A. Andreev in this study was partly performed according to the Russian Government Program of Competitive Growth of the Kazan Federal University. The study contributes to the Arctic Ecological Network (BMBF grant No 01DJ14003). The studies of A. Bobrov were supported by the project of the Russian Foundation for Basic Research N 16.04-00451: "Biogeography testate amoebae living in soil and sediments." The paper greatly benefited by helpful comments and corrections from Candace O'Connor (Fairbanks Alaska) and the two reviewers Mikhail Kanevskiy and Jason Briner and one anonymous reviewer.

\section{Appendix A. Supplementary data}

Supplementary data related to this article can be found at http:// dx.doi.org/10.1016/j.quascirev.2016.02.009.

\section{References}

Ager, T.A., Brubaker, L., 1985. Quaternary palynology and vegetational history of Alaska. In: Bryant, V.M., Holloway, R.G. (Eds.), Pollen Records of Late Quaternary North American Sediments, pp. 353-384.

Anderson, P.M., Lozhkin, A.V., 2001. The stage 3 interstadial complex (Karginskii/ middle Wisconsinan interval) of Beringia: variations in paleoenvironments and implications for paleoclimatic interpretations. Quat. Sci. Rev. 20, 93-125. http://
dx.doi.org/10.1016/S0277-3791(00)00129-3.

Andreev, A.A., Schirrmeister, L., Tarasov, P.E., Ganopolski, A., Brovkin, V., Siegert, C., Hubberten, H.-W., 2011. Vegetation and climate history in the Laptev Sea region (arctic Siberia) during Late Quaternary inferred from pollen records. Quat. Sci. Rev. 30, 2182-2199. http://dx.doi.org/10.1016/j.quascirev.2010.12.026.

Arnold, L.J., Roberts, R.G., 2009. Stochastic modelling of multi-grain equivalent dose (D e) distributions: implications for OSL dating of sediment mixtures. Quat. Geochronol. 4, 204-230. http://dx.doi.org/10.1016/j.quageo.2008.12.001.

Arnold, L.J., Bailey, R.M., Tucker, G.E., 2007. Statistical treatment of fluvial dose distributions from southern Colorado arroyo deposits. Quat. Geochronol. 2, 162-167. http://dx.doi.org/10.1016/j.quageo.2006.05.003.

Arnold, L.J., Roberts, R.G., MacPhee, R.D.E., Willerslev, E., Tikhonov, A.N., Brock, F., 2008. Optical dating of perennially frozen deposits associated with preserved ancient plant and animal DNA in north-central Siberia. Quat. Geochronol. 3, 114-136. http://dx.doi.org/10.1016/j.quageo.2007.09.002.

Bailey, R.M., Arnold, L.J., 2006. Statistical modelling of single grain quartz De distributions and an assessment of procedures for estimating burial dose. Quat. Sci. Rev. 25, 2475-2502.

Bateman, M.D., 2008. Luminescence dating of periglacial sediments and structures Boreas 37, 574-588. http://dx.doi.org/10.1111/j.1502-3885.2008.00050.x.

Begét, J.E., 1990. Mid-Wisconsinan climate fluctuations recorded in central Alaskan loess. Gèogr. Phys. Quat. 544 (3), 3-13.

Begét, J.E., 2001. Continuous Late Quaternary proxy climate records from loess in Beringia. Quat. Sci. Rev. 20, 499-507. http://dx.doi.org/10.1016/S0277-3791(00) 00102-5.

Berger, G.W., 2003. Luminescence chronology of late Pleistocene loess-paleosol and tephra sequences near Fairbanks, Alaska. Quat. Res. 60, 70-83. http:// dx.doi.org/10.1016/S0033-5894(03)00060-7.

Berglund, B.E., Ralska-Jasiewiczowa, M., 1986. Pollen analysis and pollen diagrams. In: Berglund, B.E. (Ed.), Handbook of Holocene Palaeoecology and Palaeohydrology. Wiley, Chichester, pp. 455-484.

Beug, H.-J., 2004. Leitfaden der Pollenbestimmung für Mitteleuropa und angrenzende Gebiete. Verlag Dr. Friedrich Pfeil, München, p. 542.

Bigelow, N.H., 2013. Northern North America. In: Elias, S.A. (Ed.), The Encyclopedia of Quaternary Science, vol. 4. Elsevier, Amsterdam, pp. 39-51.

Bigelow, N.H., Zazula, G.D., Atkinson, D.E., 2007. Plant macrofossil records/Arctic North America. In: Elias, S.A. (Ed.), Encyclopedia of Quaternary Science, first ed. Elsevier, Amsterdam, pp. 2434-2450.

Bobrov, A.A., Andreev, A.A., Schirrmeister, L., Siegert, Ch, 2004. Testate amoebae (Protozoa: Testacea) as bioindicators in the Late Quaternary deposits of the Bykovsky Peninsula, Laptev Sea, Russia. Paleogeogr. Paleoclimatol. Paleoecol. 209, 165-181. http://dx.doi.org/10.1016/J.PALEO.2004.02.012.

Bobrov, A.E., Kupriyanova, L.A., Litvintseva, M.V., Tarasevich, V.F., 1983. Spores and Pollen of Gymnosperms from the Flora of the European Part of the USSR. Nauka, Leningrad, p. 208 (in Russian).

Brigham-Grette, J., 2001. New perspectives on Beringian Quaternary paleogeography, stratigraphy, and glacial history. Quat. Sci. Rev. 20, 15-24. http:// dx.doi.org/10.1016/S0277-3791(00)00134-7.

Carter, M.R., Gregorich, E.G. (Eds.), 2008. Soil Sampling and Methods of Analysis, second ed. Taylor and Francis, London, p. 1224.

Craig, H., 1961. Isotopic variations in meteoric waters. Science 133, 1702-1703. http://dx.doi.org/10.1126/science.133.3465.1702.

Demuro, M., Arnold, L.J., Froese, D.G., Roberts, R.G., 2013. OSL dating of loess deposits bracketing Sheep Creek tephra beds, northwest Canada: Dim and problematic single-grain OSL characteristics and their effect on multi-grain age estimates. Quat. Geochronol. 15, 67-87. http://dx.doi.org/10.1016/ j.quageo.2012.11.003.

Douglas, T.A., Fortier, D., Shur, Y.L., Kanevskiy, M.Z., Laodong, G., Yihua, C., Bray, M.T. 2011. Biogeochemical and geocryological characteristics of wedge and Thermokarst-cave ice in the CRREL permafrost Tunnel, Alaska. Permafr. Periglac. Process. 22, 120-128. http://dx.doi.org/10.1002/ppp.709.

Dansgaard, W., 1964. Stable isotopes in precipitation. Tellus 16, 436-468. http:// dx.doi.org/10.1111/j.2153-3490.1964.tb00181.x.

Dietze, E., Hartmann, K., Diekmann, B., IJmker, J., Lehmkuhl, F., Opitz, S., Stauch, G. Wünnemann, B., Borchers, A., 2012. An end-member algorithm for deciphering modern detrital processes from lake sediments of Lake Donggi Cona, NE Tibetan Plateau, China. Sediment. Geol. 243-244, 149-180. http://dx.doi.org/10.1016/ j.sedgeo.2011.09.014.

Edwards, M.E. Hamilton, T.D. Elias, S.A., Bigelow, N.H., Krumhardt, A.P. 2003. Interglacial extension of the boreal forest limit in the Noatak valley, northwest Alaska: evidence from an exhumed river-cut bluff and debris apron. Arct. Antarct. Alp. Res. 35, 460-468.

Ehlers, J., Gibbard, P.L., 2007. The extent and chronology of Cenozoic global Glaciation. Quat. Int. 164-165, 6-20. http://dx.doi.org/10.1016/j.quaint.2006.10.008.

Elias, S.A., Brigham-Grette, J. (Eds.), 2001. Beringian Paleoenvironments - Festschrift in Honour of D.M. Hopkins. Quaternary Science Reviews, 20 (1-3), pp. $1-574$.

Evans, M.E., Jensen, B.J.L., Kravchinsky, V.A., Froese, D.G., 2011. The Kamikatsura event in the Gold Hill loess, Alaska. Geophys. Res. Lett. 38, L13302. http:// dx.doi.org/10.1029/2011GL047793.

Flora of North America Editorial Committee (Ed.), 1993-2007. Flora of North America North of Mexico, 16+ vols. New York and Oxford. Online available under. http://www.efloras.org/flora_page.aspx?flora_id=1.

French, H., Shur, Y., 2010. The principles of cryostratigraphy. Earth Sci. Rev. 110, 190-206. http://dx.doi.org/10.1016/j.earscirev.2010.04.002. 
Fritz, M., Wetterich, S., Schirrmeister, L., Meyer, H., Lantuit, H., Preusser, F. Pollard, W.H., 2012. Eastern Beringia and beyond: Late Wisconsinan and Holocene landscape dynamics along the Yukon Coastal Plain, Canada. Paleogeogr Paleoclimatol. Paleoecol. 319-320, 28-45. http://dx.doi.org/10.1016/ j.palaeo.2011.12.015.

Froese, D., Westgate, J., Preece, S., Storer, J., 2002. Age and significance of the Late Pleistocene Dawson tephra in eastern Beringia. Quat. Sci. Rev. 21, 2137-2142. http://dx.doi.org/10.1016/S0277-3791(02)00038-0.

Froese, D.G., Zazula, G.D., Reyes, A.V., 2006. Seasonality of the late Pleistocene Dawson tephra and exceptional preservation of a buried riparian surface in central Yukon Territory, Canada. Quat. Sci. Rev. 25, 1542-1551. http://dx.doi.org/ 10.1016/j.quascirev.2006.01.028.

Fuchs, M., Owen, L., 2008. Luminescence dating of glacial and associated sediments: review, recommendations and future directions. Boreas 37, 636-659. http:// dx.doi.org/10.1111/j.1502-3885.2008.00052.x.

Galbraith, R.F., Green, P.F., 1990. Estimating the component ages in a finite mixture. Nucl. Tracks Radiat. Meas. 17, 197-206.

Galbraith, R.F., Roberts, R.G., Laslett, G.M., Yoshida, H., Olley, J.M., 1999. Optical dating of single and multiple grains of quartz from Jinmium Rock Shelter Northern Australia: part I, experimental design and statistical models. Archaeometry 41, 339-364. http://dx.doi.org/10.1111/j.14754754.1999.tb00987.x.

Gillespie, A.R., Porter, S.C., Atwater, B.F. (Eds.), 2004. The Quaternary Period in the United States. In: Rose, J. (Ed.), 2004, Developments in Quaternary Science, vol. 1. Elsevier, Amsterdam, p. 584.

Griffing, C.Y., 2011. Pleistocene Climate in Alaska from Stable Isotopes in an Ice Wedge, p. pp.58. Master Thesis Graduate College University of Nevada, Las Vegas May 2011.

Grimm, E., 1991. TILIA and TILIAGRAPH. Illinois State Museum, Springfield, Illinois.

Grootes, P.M., Nadeau, M.-J., Rieck, A., 2004. 14C-AMS at the Leibniz-Labor: radiometric dating and isotope research. Nucl. Instrum. Methods Phys. Res. Sect. B 223-224, 55-61.

Gucker, C.L., 2006. Phlox hoodii [Online]. In: Fire Effects Information System. U.S. Department of Agriculture, Forest Service, Rocky Mountain Research Station, Fire Sciences Laboratory (Producer). Available: http://www.fs.fed.us/database/ feis/ [2013, June 6].

Gundelwein, A., Müller-Lupp, T., Sommerkorn, M., Haupt, E.T.K., Pfeiffer, E.-M., Wiechmann, H., 2007. Carbon in tundra soils in the Lake Labaz region of arctic Siberia. Eur. J. Soil Sci. 58, 1164-1174. http://dx.doi.org/10.1111/j.1365 2389.2007.00908.x.

Hamilton, T.D., Brigham-Grette, J., 1991. The last interglaciation in Alaska stratigraphy and paleoecology of potential sites. Quat. Int. 10-12, 49-71. http:/ dx.doi.org/10.1016/1040-6182(91)90040-U.

Hamilton, T.D., Craig, J.L., Sellmann, P.V., 1988. The Fox permafrost tunnel: a late Quaternary geologic record in central Alaska. Geol. Soc. Am. Bull. 100, 948-969.

Heslop, J.K., Walter Anthony, K.M., Sepulveda-Jauregui, A., Martinez-Cruz, K., Bondurant, A., Grosse, G., Jones, M.C., 2015. Thermokarst lake methanogenesis along a complete talik profile. Biogeosciences 12, 4317-4331. http://dx.doi.org $10.5194 /$ bg-12-4317-2015.

Hoefs, J., 1997. Stable Isotope Geochemistry. Springer-Verlag, Berlin, Heidelberg, p. 201

Hopkins, D.M., 1970. Paleoclimatic speculations suggested by new data of the location of the spruce refugium in Alaska during the last glaciation. In: Abstracts: American Quaternary Association, 1st Meeting, p. 67.

Hopkins, D.M., 1972. The paleogeography and climatic history of Beringia during late Cenozoic time. Int. J. Arct. Nordic Stud. 12, 121-150.

Hopkins, D.M., Matthews Jr., J.V., Schweger, C., Young, S.B. (Eds.), 1982. Paleoecology of Beringia. Academy Press, New York, p. 489.

Hubberten, H.-W., Andreev, A., Astakhov, V.I., Demidov, I., Dowdeswell, J.A., Henriksen, M., Hjort, C., Houmark-Nielsen, M., Jakobsson, M., Kuzmina, S. Larsen, E., Lunkka, J.P., Lysa, A., Mangerud, J., Möller, P., Saarnisto, M. Schirrmeister, L., Sher, A.V. Siegert, C., Siegert, M.J., Svendsen, J.I., 2004. The periglacial climate and environment in northern Eurasia during the last glaciation. Quat. Sci. Rev. 23, 1333-1357.

Hulten, E., 1937. Outline of the History of Arctic and Boreal Biota during the Quaternary Period. Bokffrlags Aktiebolaget Thule, Stockholm.

Jensen, B.J.L., Froese, D.G., Preece, S.J., Westgate, J.A., Stache, T., 2008. An extensive middle to late Pleistocene tephrochronologic record from east-central Alaska. Quat. Sci. Rev. 27, 411-427. http://dx.doi.org/10.1016/j.quascirev.2007.10.010.

Jensen, B.J.L., Preece, S.J., Lamothe, M., Pearce, N.J.G., Froese, D.G., Westgate, J.A., Schaefer, J., Begét, J., 2011. The variegated (VT) tephra: a new regional marker for middle to late marine isotope stage 5 across Yukon and Alaska. Quat. Int 246, 312-323. http://dx.doi.org/10.1016/j.quaint.2011.06.028.

Jorgenson, M.T., Yoshikawa, K., Kanevskiy, M., Shur, Y.L., Romanovsky, V., Marchenko, S., Grosse, G., Brown, J., Jones, B., 2008. Permafrost characteristics of Alaska. In: Kane, D., Hinkel, K. (Eds.), Proceedings of the Ninth International Conference on Permafrost. University of Alaska, Fairbanks, AK, pp. 121-122.

Kanevskiy, M.Z., French, H.M., Shur, Y.L. (Eds.), 2008. Late-Pleistocene Syngenetic Permafrost in the CRREL Permafrost Tunnel, Fox, Alaska. A Guidebook, Prepared by: Institute of Northern Engineering, University of Alaska Fairbanks for Ninth International Conference on Permafrost, June 29-July 3, 2008, pp. 1-22.

Kanevskiy, M., Shur, Y., Fortier, D., Jorgenson, M.T., Stephani, E., 2011. Cryostratigraphy of late Pleistocene syngenetic permafrost (yedoma) in northern Alaska, Itkillik River exposure. Quat. Res. 75 (3), 584-596. http://dx.doi.org/10.1016/ j.yqres.2010.12.003.
Kienast, F., Schirrmeister, L., Tarasov, P., Grosse, G., Andreev, A.A., 2008. Continental climate in the East Siberian Arctic during the Last Interglacial: implications from paleobotanical records. Glob. Planet. Change 60, 535-562. http:// dx.doi.org/10.1016/j.gloplacha.2007.07.004.

Kienast, F., Wetterich, S., Kuzmina, S., Schirrmeister, L., Andreev, A., Tarasov, P., Nazarova, L., Kossler, A., Frolova, A., Kunitsky, V.V., 2011. Paleontological records indicate the occurrence of open woodlands in a dry inland climate at the present-day Arctic coast in western Beringia during the last interglacial. Quat. Sci. Rev. 30, 2134-2159. http://dx.doi.org/10.1016/j.quascirev.2010.11.024.

Kreutzer, S., Schmidt, C., Fuchs, M.C., Dietze, M., Fischer, M., Fuchs, M., 2012. Introducing an R package for luminescence dating analysis. Anc. TL 30 (1), 1-8.

Ku, T.L., Liang, Z.C., 1984. The dating of impure carbonates with decay-series isotopes. Nucl. Instrum. Methods Phys. Res. 223, 563-571. http://dx.doi.org/ 10.1016/0167-5087(84)90710-5.

Kulig, G., 2005. Erstellung einer Auswertesoftware zur Altersbestimmung mittels Lumineszenzverfahren unter spezieller Berücksichtigung des Einflusses radioaktiver Ungleichgewichte in der 238U-Zerfallsreihe (Programming of an analysis software for age determination using luminescence methods taking into account influences of radioactive disequilibria of the $238 \mathrm{U}$ decay series). BSc thesis. Dept. of Geology, Technische Universität Bergakademie Freiberg, Germany (in German).

Kupriyanova, L.A., Alyoshina, L.A., 1972. Pollen and Spores of Plants from the Flora of European Part of USSR, vol. I. Academy of Sciences USSR, Komarov Botanical Institute, Leningrad (in Russian).

Kupriyanova, L.A., Alyoshina, L.A., 1978. Pollen and Spores of Plants from the Flora of European Part of USSR. Academy of Sciences USSR, Komarov Botanical Institute, Leningrad (in Russian).

Lachniet, M.S., Lawson, D.E., Sloat, A.R., 2012. Revised.14C dating of ice wedge growth in interior Alaska (USA) to MIS 2 reveals cold paleoclimate and carbon recycling in ancient permafrost terrain. Quat. Res. 78, 217-225. http:// dx.doi.org/10.1016/j.yqres.2012.05.007.

Matthews Jr., J.V., 1974. Wisconsin environment of interior Alaska: pollen and macrofossil analysis of a $27 \mathrm{~m}$ core from Isabella Basin (Fairbanks, Alaska). Can. J. Earth Sci. 11, 812-841.

Matthews Jr., J.V., Schweger, C.E., Janssens, J.A., 1990. The last (Koy-Yukon) interglaciation in the northern Yukon evidence from unit 4 at Ch'ijee's Bluff, Bluefish Basin. Géogr. Phys. Quat. 44, 341-362.

Merlivat, L., Jouzel, J., 1979. Global climatic interpretation of the deuterium-oxygen 18 relationship for precipitation. J. Geophys. Res. 84, 5029-5033. http:// dx.doi.org/10.1029/JC084iC08p05029.

Meyer, H., Opel, T., Laepple, T., Dereviagin, A.Yu, Hoffmann, K., Werner, M., 2015. Long-term winter warming trend in the Siberian Arctic during the mid- to late Holocene. Nat. Geosci. 8, 122-125. http://dx.doi.org/10.1038/ngeo2349.

Meyer, H., Schirrmeister, L., Andreev, A., Wagner, D., Hubberten, H.-W., Yoshikawa, K., Bobrov, A., Wetterich, S., Opel, T., Kandiano, E., Brown, J., 2010 Late glacial and Holocene isotopic and environmental history of northern coastal Alaska - results from a buried ice-wedge system at Barrow. Quat. Sci. Rev. 29, 3720-3735. http://dx.doi.org/10.1016/j.quascirev.2010.08.005.

Meyer, H., Dereviagin, A., Siegert, C., Hubberten, H.-W., 2002a. Palaeoclimate studies on Bykovsky Peninsula, North Siberia - hydrogen and oxygen isotopes in ground ice. Polarforschung 70, 37-51.

Meyer, H., Schönicke, L., Wand, U., Hubberten, H.-W., Friedrichsen, H., 2000. Isotope studies of hydrogen and oxygen in ground ice - experiences with the equilibration technique. Isotopes Environ. Health Stud. 36, 133-149. http:// dx.doi.org/10.1080/10256010008032939.

Meyer, H., Yoshikawa, K., Schirrmeister, L., Andreev, A., 2008. The Vault Creek Tunnel (Fairbanks region, Alaska) a late Quaternary paleoenvironmental permafrost record. In: Kane, D.L., Hinkel, K.M. (Eds.), Proceedings of the 9th International Conference on Permafrost, June 29-July 3, 2008. University of Alaska Fairbanks, Institute of Northern Engineering, pp. 1191-1196.

Meyer, H., Dereviagin, A.Yu, Siegert, C., Schirrmeister, L., Hubberten, H.-W., 2002b. Paleoclimate reconstruction on Big Lyakhovsky Island, North Siberia - hydrogen and oxygen isotopes in ice wedges. Permafr. Periglac. Process. 13, 91-105. http://dx.doi.org/10.1002/ppp.416.

Muhs, D.R., Ager, T.A., Begét, J.E., 2001. Vegetation and paleoclimate of the last interglacial period, central Alaska. Quat. Sci. Rev. 20, 41-61.

Muhs, D.R., Ager, T.A., Bettis III, E.A., McGeehin, J., Been, J.M., Begét, J.E., Pavich, M.J., Stafford Jr., T.W., Stevens, D.A.S.P., 2003. Stratigraphy and paleoclimatic significance of Late Quaternary loess-paleosol sequences of the Last Interglacial-Glacial cycle in central Alaska. Quat. Sci. Rev. 22, 1947-1986. http:// dx.doi.org/10.1016/S0277-3791(03)00167-7.

Muhs, D.R., Ager, T.A., Skipp, G., Beann, J., Budahn, J., McGeehin, J.P., 2008. Paleoclimatic significance of chemical weathering in loess-derived paleosols of subarctic central Alaska. Arct. Antarct. Alp. Res. 40 (2), 396-411. http://dx.doi. org/10.1657/1523-0430(07-022)[MUHS]2.0.CO;2.

Murray, A.S., Wintle, A.G., 2000. Luminescence dating of quartz using an improved single-aliquot regenerative-dose protocol. Radiat. Meas. 33, 57-73. http:// dx.doi.org/10.1016/S1350-4487(99)00253-X.

Nadeau, M.J., Grootes, P.M., Schleicher, M., Hasselberg, P., Rieck, A., Bitterling, M., 1998. Sample.throughput and data quality at the Leibniz-Labor AMS facility. Radiocarbon 40, 239-245.

Nadeau, M.J., Schleicher, M., Grootes, P.M., Erlenkeuser, H., Gottdang, A., Mous, D.J.W., Sarnthein, J.M., Willkomm, H., 1997. The Leibniz-labor facility at the Christian-Albrecht-university, Kiel, Germany. Nucl. Instrum. Methods Phys. Res. 123, 22-30. http://dx.doi.org/10.1016/S0168-583X(96)00730-6. 
Opel, T., Dereviagin, A., Meyer, H., Schirrmeister, L., Wetterich, S., 2010. Paleoclimatic information from stable water isotopes of Holocene ice wedges at the Dmitrii Laptev Strait (Northeast Siberia). Permafr. Periglac. Process. 22 (1), 84-100. http://dx.doi.org/10.1002/ppp.667.

Otte, V., Wesche, K., Dressler, S., Zizka, G., Hoppenrath, M., Kienast, F., 2011. The new Herbarium Senckenbergianum: old institutions under a new common roof. In: Stuessy, T.F. (Ed.), Plant Systematics World. Taxon, 60(2), pp. 617-618.

Preece, S.J., Westgate, J.A., Froese, D.G., Pearce, N.J.G., Perkins, W.T., 2011. A catalogue of late Cenozoic tephra beds in the Klondike goldfields and adjacent areas, Yukon Territory. Can. J. Earth Sci. 48, 1386-1418. http://dx.doi.org/10.1139/E10110.

Péwé, T.L., 1975. Quaternary geology of Alaska. U.S. Geological Survey Professional Paper 835, p. 145.

Reille, M., 1992. Pollen et spores d'Europe et d'Afrique du nord. Laboratoire de Botanique Historique et Palynologie, Marseille (in French).

Reille, M., 1995. Pollen et spores d'Europe et d'Afrique du nord, supplement 1. Laboratoire de Botanique Historique et Palynologie, Marseille (in French).

Reille, M., 1998. Pollen et spores d'Europe et d'Afrique du nord, supplement 2. Laboratoire de Botanique Historique et Palynologie, Marseille (in French).

Reyes, A.V., Froese, D.G., Jensen, B.J.L., 2010a. Permafrost response to last interglacial warming: field evidence from non-glaciated Yukon and Alaska. Quat. Sci. Rev. 29, 3256-3274. http://dx.doi.org/10.1016/j.quascirev.2010.07.013.

Reyes, A.V., Jensen, B.J.L., Zazula, G.D., Ager, t.A., Kuzmina, S., La Farge, C., Froese, D.G., 2010b. A late-Middle Pleistocene (Marine isotope Stage 6) vegetated surface buried by old Crow tephra at the Palisades, interior Alaska. Quat. Sci. Rev. 29, 801-811. http://dx.doi.org/10.1016/j.quascirev.2009.12.003.

Reyes, A.V., Zazula, G.D., Kuzmina, S., Ager, T.A., Froese, D.G., 2011. Identification of last interglacial deposits in eastern Beringia: a cautionary note from the Palisades, interior Alaska. J. Quat. Sci. 26 (3), 345-352. http://dx.doi.org/10.1002/ jqs.1464.

Schirrmeister, L., Oezen, D., Geyh, M.A., 2002. 230Th/U dating of frozen peat, Bol'shoy Lyakhovsky Island (North Siberia). Quat. Res. 57, 253-258. http:// dx.doi.org/10.1006/qres.2001.2306.

Schirrmeister, L., Kunitsky, V.V., Grosse, G., Wetterich, S., Meyer, H., Schwamborn, G. Babiy, O., Derevyagin, A.Y., Siegert, C., 2011. Sedimentary characteristics and origin of the Late Pleistocene ice complex on North-East Siberian Arctic coastal lowlands and islands - a review. Quat. Int. 241, 3-25. http://dx.doi.org/10.1016/ j.quaint.2010.04.004.

Schirrmeister, L., Froese, D., Tumskoy, V., Grosse, G., Wetterich, S., 2013. Yedoma late Pleistocene ice-rich syngenetic permafrost of Beringia. In: Elias, S.A. (Ed.), The Encyclopedia of Quaternary Science. Elsevier, Amsterdam, pp. 542-552.

Schwamborn, G., Schirrmeister, L., Frütsch, F., Diekmann, B., 2012. Geografiska Annaler Series A. Phys. Geogr. 94, 481-499. http://dx.doi.org/10.1111/j.14680459.2012.00472.x.

Schwarcz, H.P., Latham, A.G., 1989. Dirty calcites: 1. Uranium series dating of contaminated calcite using leachates alone. Chem. Geol. 80, 35-43. http:// dx.doi.org/10.1016/0168-9622(89)90046-8.

Schweger, C.E., Janssens, J.A., 1980. Paleoecology of the Boutellier non-glacial interval, St. Elias mountains, Yukon Territory, Canada. Arct. Alp. Res. 12, 309-317.

Schweger, C.E., Matthews, J.V., 1991. The last (Koy-Yukon) interglaciation in the Yukon: comparisons with Holocene and interstadial pollen records. Quat. Int 10-12, 85-94. http://dx.doi.org/10.1016/1040-6182(91)90042-M.

Sellmann, P.V., 1967. Geology of the USA CRREL Permafrost Tunnel, Fairbanks, Alaska. US Army CRREL, Hanover, p. 22. New Hampshire Technical Report 199.

Sellmann, P.V., 1972. Geology and Properties of Material Exposed in the USA. CRREL Permafrost Tunnel. US Army CRREL, Hanover, p. 16. New Hampshire Special Report 177.

Shur, Y., French, H.M., Bray, M.T., Anderson, D.A., 2004. Syngenetic permafrost growth: cryostratigraphic observations from the CRREL tunnel near Fairbanks, Alaska. Permafr. Periglac. Process. 15, 339-347. http://dx.doi.org/10.1002/ ppp.486.

Stockmarr, J., 1971. Tablets with spores used in absolute pollen analysis. Pollen Spores 13, 614-621.

St-Jean, M., Lauriol, B., Clark, I.D., Lacelle, D., Zdanowicz, C., 2011. Investigation of ice-wedge infilling processes using stable oxygen and hydrogen isotopes, crystallography and occluded gases $\left(\mathrm{O}_{2}, \mathrm{~N}_{2}, \mathrm{Ar}\right)$. Permafr. Periglac. Process. 22, 49-64. http://dx.doi.org/10.1002/ppp.680.

Strauss, J., Schirrmeister, L., Grosse, G., Wetterich, S., Ulrich, M., Herzschuh, U., Hubberten, H.-W., 2013. The deep permafrost carbon pool of the Yedoma region in Siberia and Alaska. Geophys. Res. Lett. 40 (23), 6165-6170. http://dx.doi.org/ 10.1002/2013GL058088.

Svendsen, J.I., Alexanderson, H., Astakhov, V.I., Demidov, I., Dowdeswell, J.A., Funder, S., Gataullin, V., Henriksen, M., Hjort, C., Houmark-Nielsen, M.,
Hubberten, H.-W., Ingolfsson, O., Jacobsson, M., Kjær, K., Larsen, E., Lokrantz, H., Lunkka, J.P., Lysa, A., Mangerud, J., Matioushkov, A., Murray, A., Moeller, P., Niessen, F., Nikolskaya, O., Polyak, L., Saarnisto, M., Siegert, C., Siegert, M.J., Spielhagen, R.F., Stein, R., 2004. Late Quaternary ice sheet history of northern Eurasia. Quat. Sci. Rev. 23, 1229-1272. http://dx.doi.org/10.1016/ j.quascirev.2003.12.008.

USDA, 2013. USDA, ARS, National Genetic Resources Program. Germplasm Resources Information Network - (GRIN) [Online Database]. National Germplasm Resources Laboratory, Beltsville, Maryland. http://www.ars-grin.gov/cgi-bin/ npgs/html/index.pl (04 June 2013).

van Geel, B., 2001. Non-pollen palynomorphs. In: Smol, J.P., Birks, H.J.B., Last, W.M (Eds.), Terrestrial Algal and Siliceous Indicators, Tracking Environmenta Changes Using Lake Sediments, vol. 3. Kluwer Academic Press, Dordrecht, pp. 99-119.

Viereck, L.A., 1983. Vegetation. In: Brown, J., Kreig, R.A. (Eds.), Guidebook to Permafrost and Related Features along the Elliott and Dalton Highways, Fox to Prudhoe Bay, AlaskaFourth International Conference on Permafrost July 18-22, 1982, Fairbanks. University of Alaska, U.S.A, pp. 26-31.

Weltje, G., 1997. End-member modeling of compositional data: numerical-statistical algorithms for solving the explicit mixing problem. Math. Geol. 29, 503-549. http://dx.doi.org/10.1007/BF02775085.

West, F.H. (Ed.), 1996. American Beginnings - the Preshistory and Paleoecology of Beringia. University of Chicago Press, p. 576.

Westgate, J.A., Stemper, B.A., Péwé, T.L., 1990. A 3 m.y. record of Pliocene-Pleistocene loess in interior Alaska. Geology 18, 858-861. http://dx.doi.org/10.1130/00917613(1990)018<0858:AMYROP>2.3.CO;2.

Westgate, J.A., Preece, S.J., Kotler, E., Hall, S., 2000. Dawson tephra: a prominent stratigraphic marker of Late Wisconsinan age in west-central Yukon, Canada. Can. J. Earth Sci. 37, 621-627.

Westgate, J.A., Preece, S.J., Froese, D.G., Pearce, N.J.G., Roberts, R.G., Demuro, M. Hart, W.K., Perkins, W., 2008. Changing ideas on the identity and stratigraphic significance of the Sheep Creek tephra beds in Alaska and the Yukon Territory northwestern North America. Quat. Int. 178, 183-209. http://dx.doi.org/10.1016/ j.quaint 2007.03.009.

Wetterich, S., Kuzmina, S., Andreev, A.A., Kienast, F., Meyer, H., Schirrmeister, L. Kuznetsova, T., Sierralta, M., 2008. Palaeoenvironmental dynamics inferred from late Quaternary permafrost deposits on Kurungnakh Island, Lena Delta Northeast Siberia, Russia. Quat. Sci. Rev. 27, 1523-1540. http://dx.doi.org 10.1016/j.quascirev.2008.04.007.

Wetterich, S., Schirrmeister, L., Andreev, A.A., Pudenz, M., Plessen, B., Meyer, H. Kunitsky, V.V., 2009. Eemian and Lateglacial/Holocene palaeoenvironmenta records from permafrost sequences at the Dmitry Laptev Strait (NE Siberia, Russia). Palaeogeogr. Palaeoclimatol. Palaeoecol. 279, 73-95. http://dx.doi.org/ 10.1016/j.palaeo.2009.05.002.

Wetterich, S., Rudaya, N., Andreev, A.A., Opel, T., Schirrmeister, L., Meyer, H., Tumskoy, V., 2014. Ice complex formation in arctic East Siberia during the MIS3 interstadial. Quat. Sci. Rev. 84, 39-55. http://dx.doi.org/10.1016 j.quascirev.2013.11.009.

Wetterich, S., Tumskoy, V., Rudaya, N., Kuznetsov, V., Maksimov, F., Opel, T. Meyer, H., Andreev, A.A., Schirrmeister, L., 2016. Ice complex permafrost of MIS5 age in the Dmitry Laptev Strait coastal region (East Siberian Arctic). Quat. Sci. Rev. 132, 1-16. http://dx.doi.org/10.1016/j.quascirev.2015.11.016.

White, R.E., 2006. Principle and Practice in Soil Science. Blackwell, Malden, Mass p. 266.

WMO 702720: http://www7 ncdc noaa gov/CDO/cdoselect.cmd.

Wooller, M.J., Zazula, G.D., Blinnikov, M., Gaglioti, B.V., Bigelow, N.H., Sanborn, P. Kuzmina, S., La Farge, C., 2011. The detailed palaeoecology of a midWisconsinan interstadial (ca. $32000{ }^{14} \mathrm{C}$ a BP) vegetation surface from interior Alaska. J. Quat. Sci. 26 (7), 746-756. http://dx.doi.org/10.1002/jqs.1497.

Yoshikawa, K., Hinzman, L.D., 2003. Shrinking thermokarst ponds and groundwater dynamics in discontinuous permafrost near Council, Alaska. Permafr. Periglac Process. 14, 151-160. http://dx.doi.org/10.1002/ppp.451.

Zazula, G.D., Froese, D.G., Elias, S.A., Kuzmina, S., La Farge, C., Reyes, A.V. Sanborn, P.T., Schweger, C.E., Smith, C.A.S., Mathewes, R.W., 2006. Vegetation buried under Dawson tephra (25,300 14C years BP) and locally diverse late Pleistocene paleoenvironments of Goldbottom Creek, Yukon, Canada. Palaeogeogr. Palaeoclimatol. Palaeoecol. 242, 253-286. http://dx.doi.org/10.1016/ j.palaeo.2006.06.005

Zazula, G.D., Froese, D.G., Elias, S.A., Kuzmina, S., Mathewes, R.W., 2011. Early Wisconsinan (MIS 4) Arctic ground squirrel middens and a squirrel-eye-view of the mammoth-steppe. Quat. Sci. Rev. 30, 2220-2237. http://dx.doi.org/10.1016 j.quascirev.2010.04.019. 